1994

\title{
Auditory Evoked Potentials of the Loggerhead Sea Turtle (Caretta caretta)
}

Soraya M. Bartol

College of William and Mary - Virginia Institute of Marine Science

Follow this and additional works at: https://scholarworks.wm.edu/etd

Part of the Zoology Commons

\section{Recommended Citation}

Bartol, Soraya M., "Auditory Evoked Potentials of the Loggerhead Sea Turtle (Caretta caretta)" (1994). Dissertations, Theses, and Masters Projects. Paper 1539617675.

https://dx.doi.org/doi:10.25773/v5-w3za-nw09

This Thesis is brought to you for free and open access by the Theses, Dissertations, \& Master Projects at W\&M ScholarWorks. It has been accepted for inclusion in Dissertations, Theses, and Masters Projects by an authorized administrator of W\&M ScholarWorks. For more information, please contact scholarworks@wm.edu. 
AUDITORY EVOKED POTENTIALS OF

THE LOGGERHEAD SEA TURTLE (CARETTA CARETTA)

A Thesis
Presented to
The Faculty of the School of Marine Science
The college of William and Mary in Virginia

In Partial Fulfillment

of the Requirements for the Degree of

Masters of Arts

\author{
by \\ Soraya E. Moein \\ 1994
}




\section{APPROVAL SHEET}

This thesis is submitted in partial fulfillment of the requirements for the degree of

Masters of Arts

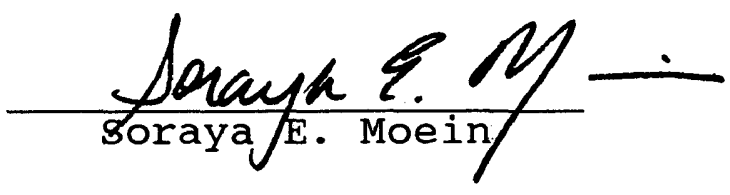

Approved, July 1994
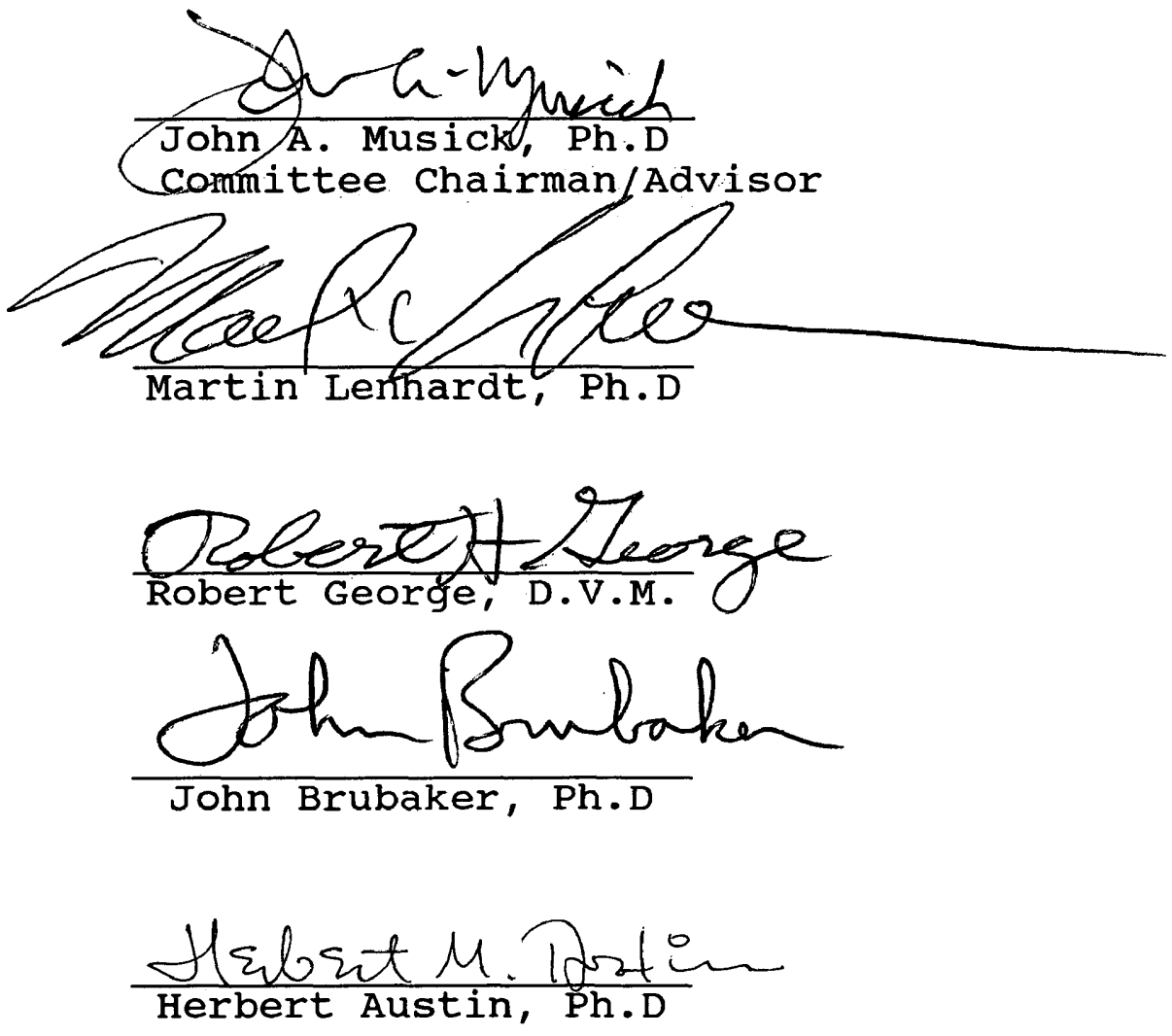
This thesis is dedicated to my parents, George and Jane Moein, who provide an immeasurable amount of guidance, patience, and love. 
TABLE OF CONTENTS

Page

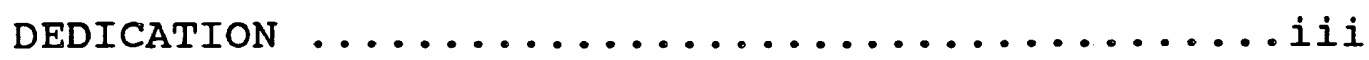

ACKNOWLEDGEMENTS $\ldots \ldots \ldots \ldots \ldots \ldots \ldots \ldots \ldots \ldots$

LIST OF TABLES $\ldots \ldots \ldots \ldots \ldots \ldots \ldots \ldots \ldots \ldots \ldots \ldots$

LIST OF FIGURES $\ldots \ldots \ldots \ldots \ldots \ldots \ldots \ldots \ldots \ldots \ldots \ldots \ldots$

ABSTRACT $\ldots \ldots \ldots \ldots \ldots \ldots \ldots \ldots \ldots \ldots \ldots \ldots \ldots \ldots \ldots \ldots \ldots \ldots$

INTRODUCTION $\ldots \ldots \ldots \ldots \ldots \ldots \ldots \ldots \ldots \ldots \ldots$

MATERIALS AND METHODS................. 14

Bioelectric measurement ............... 14

Threshold measurements ................. 19

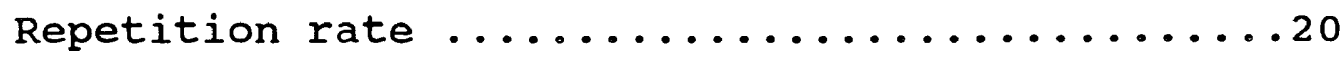

Masking experiment $\ldots \ldots \ldots \ldots \ldots \ldots \ldots \ldots 22$

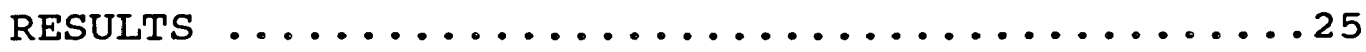

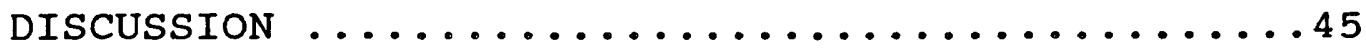

Threshold ........................ 45

Repetition rate $. \ldots \ldots \ldots \ldots \ldots \ldots \ldots . \ldots . \ldots 49$

Masking experiment $\ldots \ldots \ldots \ldots \ldots \ldots \ldots \ldots 1$

Conclusions .........................

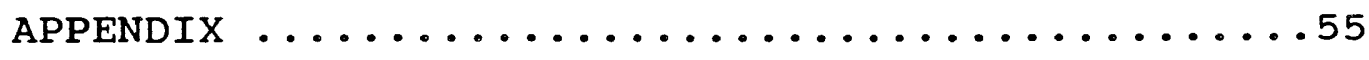

LITERATURE CITED $\ldots \ldots \ldots \ldots \ldots \ldots \ldots \ldots \ldots \ldots \ldots \ldots \ldots$

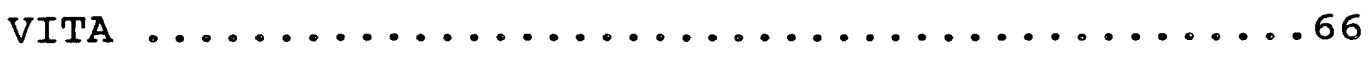


ACKNOWLEDGEMENTS

I would like to thank my committee members for their excellent help and guidance. I would like to especially acknowledge Dr. John Musick for his undying eagerness to explore new avenues of research. I am grateful to the past and present students and aides of the turtle project, especially J. Keinath, D. Keinath, B. Bell, and R. Pemberton for help with this project. John and Deb deserve special gratitude for being both good mentors and good friends. I am indebted to the poundnetters who supplied my research with live turtles, especially the Jetts. I would like to thank Buddy Bunting for the illustration of the loggerhead sea turtle middle ear. Finally, I could not have survived this project without Ian Bartol's encouragement and understanding.

This research was funded by the United states Army Corps of Engineers, contract \# DACW39-92-R0117. All research was conducted under the U.S. Fish and Wildlife Endangered Species Permit issued to J.A. Musick. 


\section{LIST OF TABLES}

Table

Page

1. Tag numbers, dates captured and released, weight, and length of the 35 loggerhead turtles used in the three phases of the

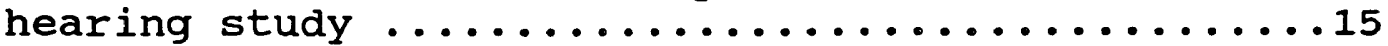

2. Threshold level of hearing with a click stimulus for loggerhead sea turtles measured in both acceleration and SPL .........26

3. Threshold data for six loggerhead turtles using the tone bursts with frequencies centered around $250 \mathrm{~Hz}, 500 \mathrm{~Hz}, 750 \mathrm{~Hz}$,

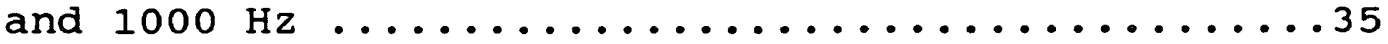

4. Latency between peak I and peak $V$ collected from the auditory evoked potential waves

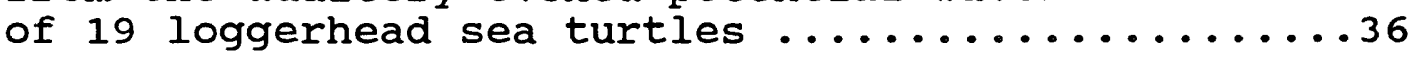

5. $\mathrm{R}^{2}$ and $\mathrm{p}$-values for the regression analysis performed on 19 loggerhead sea turtles ..........43

6. Measurements of click intensity and white noise intensity levels for the last point at which the loggerhead turtle could

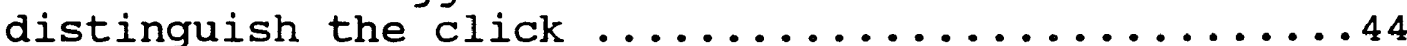




\section{LIST OF FIGURES}

Figure

Page

1. Schematic drawing of the loggerhead

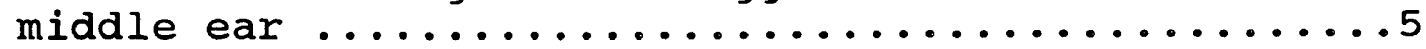

2. Auditory evoked potentials collected from the loggerhead sea turtle ...............12

3. Placement of the electrodes and mechanical vibrator on the head of the loggerhead sea turtle when collecting auditory evoked

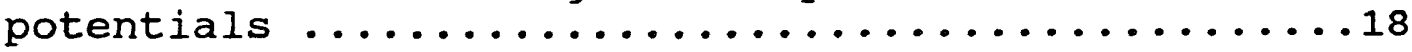

4. Representative drawing of the EEG waves measured from a loggerhead sea turtle while

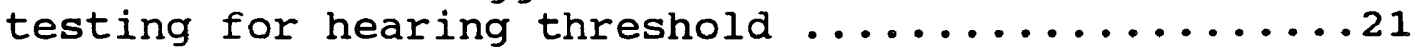

5. An example of waves collected from a loggerhead sea turtles while examining for the effect of stimulus rate on the

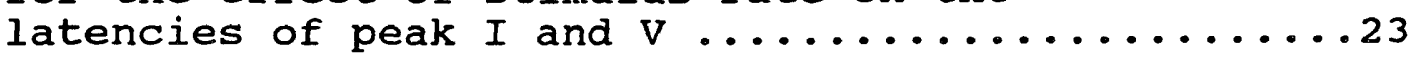

6. Representative evoked potential waves collected when white noise and a broadband click were used as the stimuli for a

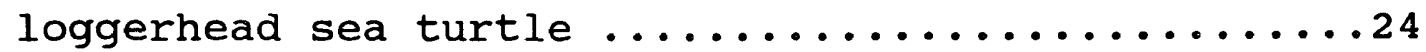

7. Threshold levels collected from turtle QQM800/QQM785 for 250, 500, 750, and

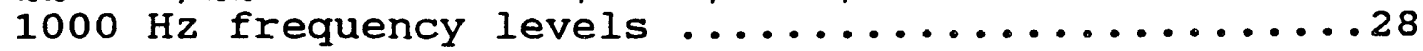

8. Threshold levels collected from turtle QQZ418/QQZ414 for 250, 500, 750, and

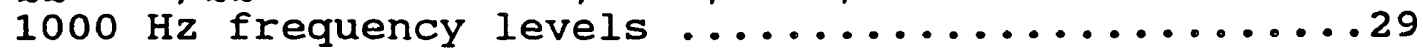

9. Threshold levels collected from turtle SSB805/SSB806 for 250, 500, 750, and

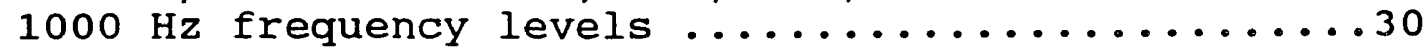

10. Threshold levels collected from turtle PPX804/PPX817 for 250, 500, 750, and

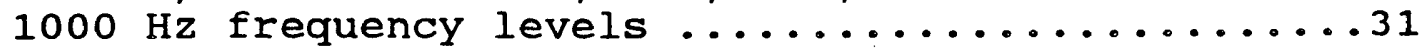


Figure

Page

11. Threshold levels collected from turtle QQM791/PPX807 for 250, 500, 750, and

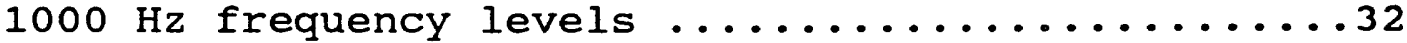

12. Threshold levels collected from turtle QQZ417/QQZ401 for 250, 500, 750, and

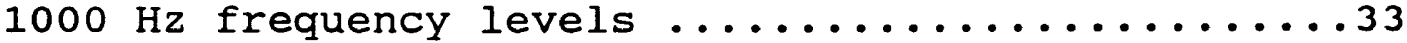




\section{ABSTRACT}

Repulsion from hopper dredges using auditory stimuli is one frequently proposed solution for reducing incidental mortalities of sea turtles. However, before this tactic can be assessed, research must first be performed on the auditory mechanism of sea turtles, an area underdeveloped in the literature. In this study, threshold for response to stimuli and the effects of stimuli and white noise on the threshold were determined for the loggerhead sea turtle, Caretta caretta.

35 juvenile loggerhead turtles caught in the Chesapeake Bay were used in this study. A computer capable of delivering stimuli and receiving bioelectric activity via electrodes implanted in the loggerhead sea turtle was used. Either a low frequency broadband click or tone bursts (250, 500,750 or $1000 \mathrm{~Hz}$ ) were deliver by a bone vibrator to the turtle's tympanum. Intensity and frequency of stimulus was manipulated for the threshold experiment. Rate of stimulus presentation and intensity of white noise were manipulated for the rate and masking experiments, respectively.

The maximum sensitivity was in the low frequency region of at least 250 to $1000 \mathrm{~Hz}$ with a maximum sensitivity at 250 $\mathrm{Hz}$ of $-24.4 \mathrm{~dB}$ re: 1 gravity unit. The broadband click produced clear auditory response with a mean threshold of $-10.8 \mathrm{~dB}$ re: 1 gravity unit and $8.5 \mathrm{~dB}$ re: 1 dynes $/ \mathrm{cm}^{2}$. In the rate experiment, interpeak latencies for peak I and peak $\mathrm{V}$ were significantly dependent on rate. In the masking experiment, signal to noise ratios ranged from -3.5 to -8.5 $\mathrm{dB}(\mathrm{x}=-5.2 \pm 2.4)$.

The broadband click stimuli elicited synchronous neural activity of the hair cells and was determined to be the most efficient stimulus to use when recording threshold from the loggerhead sea turtle. An increase in the stimulus rate resulted in the disruption of neural synchrony and thus interpeak latencies increased with rate of stimulus. Finally, loggerheads appear to be able to resolve the stimulus through a high level of white noise. These techniques of auditory evoked potentials may be utilized in two fields of applied research: the development of an acoustic repelling device and the identification of diseases of the brain of sea turtles. 
AUDITORY EVOKED POTENTIALS OF

THE LOGGERHEAD SEA TURTLE (CARETTA CARETTA) 
INTRODUCTION

Hopper dredging is the most effective way of widening and deepening channels to accommodate deep draft shipping traffic. However, this procedure alters marine habitat and disrupts residing marine life. One group of marine organisms largely affected by dredging is sea turtles, animals protected by the Endangered Species Act of 1973 (Dickerson et al., 1991, Studt, 1985). Sea turtles have been found entrained and killed during dredging operations (Hopkins \& Richardson, 1984). These operations may harm all five species of sea turtles found along the eastern United States coast: the loggerhead (caretta caretta), green (Chelonia mydas), Kemp's ridley (Lepidochelys kempii), hawksbill (Eretomochelys imbricata), and the leatherback (Dermochelys coriacea). However, the National Marine Fisheries Service (NMFS) has concluded that only Kemp's ridley, loggerhead, and green sea turtles may be at risk by hopper dredging activities because of their geographic distribution and life history attributes (Grossblatt, 1990).

The concern over the mortality of sea turtles from dredging increased in 1980 at Port Canaveral Channel, 
Florida, when an unusually large number of loggerheads were present. Over 77 loggerheads were killed by dredges during the removal of $1.9 \times 10^{6} \mathrm{~m}^{3}$ sediment (Carr et al., 1981; Joyce, 1982). When mortality from dredging was first recognized, NMFS and the US Army Corps of Engineers (COE) trawled the channel and relocated approximately 1,250 loggerheads from Canaveral channel to offshore locations. This relocation project was not entirely successful, however, because many loggerheads returned to the channels immediately (Grossblatt, 1990).

Other courses of action are being explored to reduce mortalities from hopper dredging, including the appointment of observers on hopper dredges to identify turtle parts, modification of dredge dragheads to displace turtles, radio and sonic tracking in navigation channels to determine habitat utilization, and investigation of repulsion of sea turtles from dredges using auditory stimuli (Grossblatt, 1990). Repulsion via auditory stimuli may help reduce the incidental take of sea turtles by dredges, however, the feasibility of an acoustic repelling device must be evaluated.

Until recently, little research has been performed on the auditory mechanism of sea turtles. Almost nothing is known about how sea turtles use hearing under natural conditions or its role in their adaptive behavior. Sea turtles have been reported to show a lack of response to even intense sounds (Wever, 1978). Thus, a number of 
factors, including anatomy, behavior responses, and electrophysiological response to sound, should be considered when evaluating the hearing capabilities of sea turtles.

The anatomy of the turtle ear has been well researched (Lenhardt et al., 1985; Manley, 1970; McGill, 1960; Patterson, 1966; Wever, 1978). Sea turtles have a thick layer of subtympanal fat, a feature which distinguishes them from both terrestrial and semiaquatic species (Fig 1). There is no external ear, and the tympanum is a continuation of the facial tissue. Removal of the tympanum produces only negligible change in the displacement of the columella (middle ear bone) which suggests that the tympanum is a poor aerial receptor (Moffat and Capranica, 1978). Unlike mammals, sea turtles have no pinnae, ear canal or elongated coiled cochlea, which are associated with sensitivity, localization, and the determination of frequency range (Wever, 1978).

Sea turtles have an ossicular mechanism consisting of two elements, the columella and the extracolumella. The extracolumella is a cartilaginous disk under the tympanic membrane which is attached to the columella by ligaments. The columella is long and curved with the majority of the mass concentrated at each end. The proximal end expands within the oval window to form a funnel shaped stapes. Unique to all sea turtles are the stapedo-saccular strands; fibrous strands which connect the stapes and the oval window to the saccule. The stapedo-saccular strands presumably 
Figure 1. Schematic drawing of the loggerhead middle ear. 


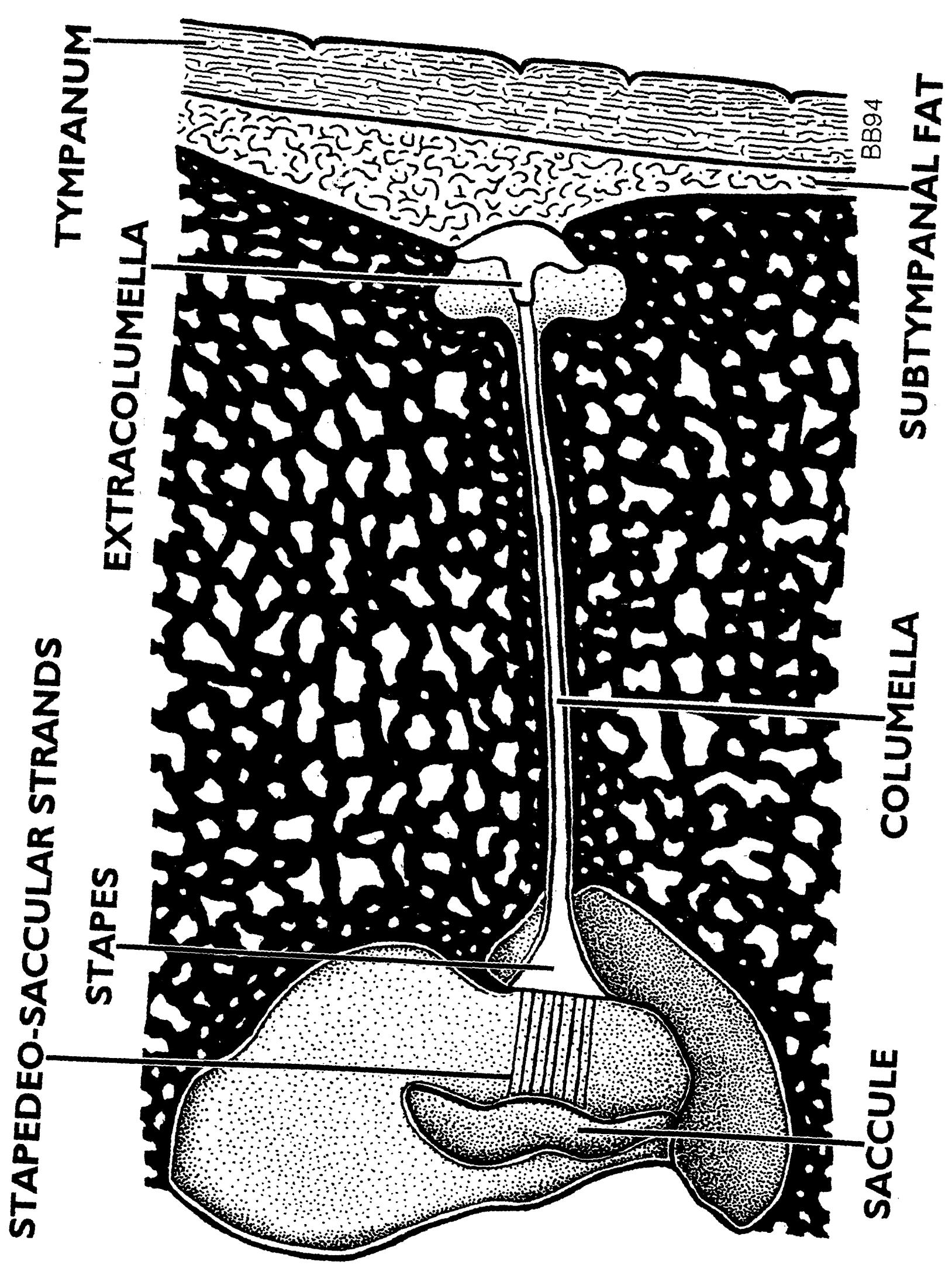


relay vibrational energy to the saccule (Lenhardt et al., 1985; Wever and Vernon, 1956). The shape of the columella and its interactions with the cochlea and saccule suggest that the sea turtle's middle ear is a compromise for sound conduction through two media, bone and water. Through the utilization of bone conduction, sound flows via the bones and soft tissues of the turtle. The ear drum acts as a release mechanism rather than a sound receptor (Bekesy, 1948; Lenhardt, 1982; Lenhardt et al., 1983; Lenhardt and Harkins, 1983; Tonndorf, 1972). High frequencies are attenuated by bone which limits the range of frequency heard by sea turtles to low frequencies. Furthermore, it is believed that the thick layer of subtympanal fat functions as additional mass loading to the ear and consequently lowers the frequency sensitivity (Tonndorf, 1972).

studies performed on the cochlear hair cells of turtles are extensive (Art et al., 1985, Crawford and Fettiplace, 1980; Fettiplace and Crawford, 1980; Manley, 1974; Paton et al., 1976). These experiments were performed on the isolated half-head of the red eared turtle (Pseudemys scripta elagans). Fettiplace and Crawford (1980) compared membrane potential changes to the frequency of the acoustic stimulation and concluded that cochlear hair cells convert the basilar membrane motion (the nerve terminals, hair cells, and supporting cells) into electrical signals. These electric signals are then received by the auditory nerve. In another study, Crawford and Fettiplace (1980) established 
frequency-threshold curves of auditory nerve fibers (hair cells) for eleven red eared turtles by recording the responses of single cochlear hair cells. These threshold curves fell between $30-700 \mathrm{~Hz}$ with no evidence of discontinuity.

While the range of frequencies turtles may hear has been established through the study of the turtle anatomy and physiology, the appropriate presentation of these frequencies to turtles has not. Low frequencies may be presented to the loggerhead as tones, clicks, or modulated frequencies presented pulsed or continuously. The ability of the turtle to analyze sound can depend on how sound stimuli are presented (Wever, 1949). One method of examining this ability to analyze sound is by performing conditioning or localization experiments. Early studies used an aerial sound source only a few centimeters away (Andrews, 1915; Chernomidikov, 1958; Karimova; 1958; Kuroda, 1923; Kuroda, 1925; Poliakov 1930). However, these behavioral studies could not be replicated. For instance, Andrews (1915) trained turtles of the genus Chrysemys to approach food at the sound of a bell but not to approach food at the sound of a whistle. Kuroda tried to repeat this study, using the same methodology, in both 1923 and 1925, without success. Poliakov (1930) conditioned the european pond turtle (Emys orbicularis) to withdraw its head using a variety of sounds, bells, noises, and pure tones, Chernomidikov (1958) and Karimova (1958) attempted to 
replicate this experiment, but were unsuccessful.

Furthermore, there are no published underwater localization studies for sea turtles. Thus, the appropriate presentation of the frequencies, whether tones or clicks presented continuously, pulsed or intermingled, has not yet been established.

A few attempts have been made to collect

electrophysiological responses to the aerial stimulation of the turtle's hearing apparatus. Wever and Vernon (1931) were successful in attaining synchronized responses from the eighth cranial nerve (the auditory nerve) of the painted turtle (Chrysemys picta) with responses occurring below 500 Hz. Adrian et al. (1938) reported a response of the eighth cranial nerve of the eastern box turtle (Terapene carolina) and the spur-thighed tortoise (Testudo graeca) using tones of $400 \mathrm{~Hz}$. Finally, Wever (1978) measured the sensitivity of cochlear potentials of 14 species of turtles using an aerial sound source.

Electrophysiological research on sea turtles, however, has been less promising. Foa and Peroni (1930) applied an electrode to the eighth cranial nerve of the loggerhead sea turtle and used organ pipe tones between 16.5 and $132 \mathrm{~Hz}$ as the aerial stimulus. However, the resulting potentials did not appear to relate to the stimulus. The only other attempt to collect. electrophysiological data from sea turtles was one study performed on the green sea turtle (Ridgeway et al., 1969). The frequencies tested on these 
turtles ranged from 50 to $2000 \mathrm{~Hz}$. The results revealed that green sea turtles detected limited sound frequencies (200-700 $\mathrm{Hz})$ and displayed a high level of sensitivity at the low tone region of about $400 \mathrm{~Hz}$. Moreover, with an increase in frequencies, their range of sensitivity declined by a rate of $40 \mathrm{~dB}$ per octave.

Threshold levels also play an important role in evaluating turtle hearing responses. Threshold of hearing is the lowest stimulus intensity below which the stimulus ceases to be heard (Gibson, 1982). It appears that the use of feeding/conditioning response, though adequate for generalized studies, is not a reliable method in determination of thresholds (Tavolga, 1963). There has yet to be established a clear cut criterion of response behavior to determine threshold. A standard behavior has not been identified because thresholds are a statistically determined point around which there exists a probability of positive responses both above and below the determined threshold. Consequently, as the researcher approaches the subject's threshold level, behavior of the test subject can become variable (Tavolga, 1963). In order to obtain a more reliable measurement of a threshold level to a stimulus, auditory evoked potentials can be measured.

Auditory evoked potentials are electric responses to the stimulation of the nervous system; they are the sum of the action potentials of the initial discharge of many neurons firing in synchrony due to stimulation. These 
potentials consist of a series of waves identified by amplitude and latency. However, a problems occurs when measuring single auditory evoked responses. Excessive biological noise of ongoing neural and muscular electrical activity introduces components unrelated to the stimulus (Spehlmann, 1985). This problem can be solved by summing and averaging single auditory responses. In the absence of stimulation, the electroencephalogram (EEG) is random at any one moment, thus there are as many positive as negative values at any point. When these random values are averaged, the EEG should appear as a flat line. Alternatively, if a neural discharge occurs at a certain time (latency) as the stimulus is presented, then the summation and averaging of many response times locked to the stimulus will produce an exaggeration of the single response (Gelfand, 1990).

Auditory evoked responses to stimuli can be described by their response latency. The earliest brainstem responses occur within the first eight milliseconds and have been coined the "Jewett bumps" (Chiappa et al., 1979; Jewett, 1970; Jewett et al., 1970). Studies on humans and cats have led to the mapping of these peaks as follows: peak $I$, auditory nerve; peak II, cochlear nuclei; peak III, superior olivary complex; peak IV, midbrain; and peak V, inferior colliculus (Buchwald and Huang, 1975; Chiappa et al., 1979; Markand, 1994; Rowe, 1978). The absolute locations of the peaks in the sea turtle are not conclusive, in fact it is thought that the peaks beyond peak I are the 
result of the summation of multiple sources. Of the peaks found in the first $8 \mathrm{~ms}$, peak $\mathrm{V}$ is the largest and most predictable (Gelfand, 1990), and thus can be used as the index peak to establish threshold (Fig 2).

Two variations of the threshold test parameters can be examined to test their effect on the synchrony of the neural response collected by auditory evoked potentials. The rate of the stimulus can be tested to determine its effect on the conduction time of peak I and V. Secondly, the ability of the loggerhead to distinguish a stimulus through ambient noise can be investigated using a masker of white noise.

In humans, increasing the click stimulus rate prolongs all the peaks, but the latency of peak I appears to be the least affected (Chiappa et al., 1979; Markand, 1994). It is possible to examine the effectiveness of the turtle's ability to analyze sound at different rates of presentation by examining the $I-V$ interpeak conduction time, the time taken for the stimulus to travel between the origins of these two peaks. This analysis can be accomplished by examining the auditory evoked potentials and their peak's latencies at various clicks per second.

Masking transpires when the threshold of audibility of the stimulus is raised by the introduction of another sound (noise) (Green, 1976; Yost and Neilsen, 1977) . BY incorporating white noise with the stimulus, the signal and noise levels at which the masker wipes out the synchrony of the stimulus and the threshold for the stimulus is canceled, 
Figure 2. Auditory evoked potentials collected from the loggerhead sea turtle. The two waves represent the output from the left and right ear. Peak I, II, III, and V are the earliest brainstem responses which occur within the first 10 ms of stimulation. 


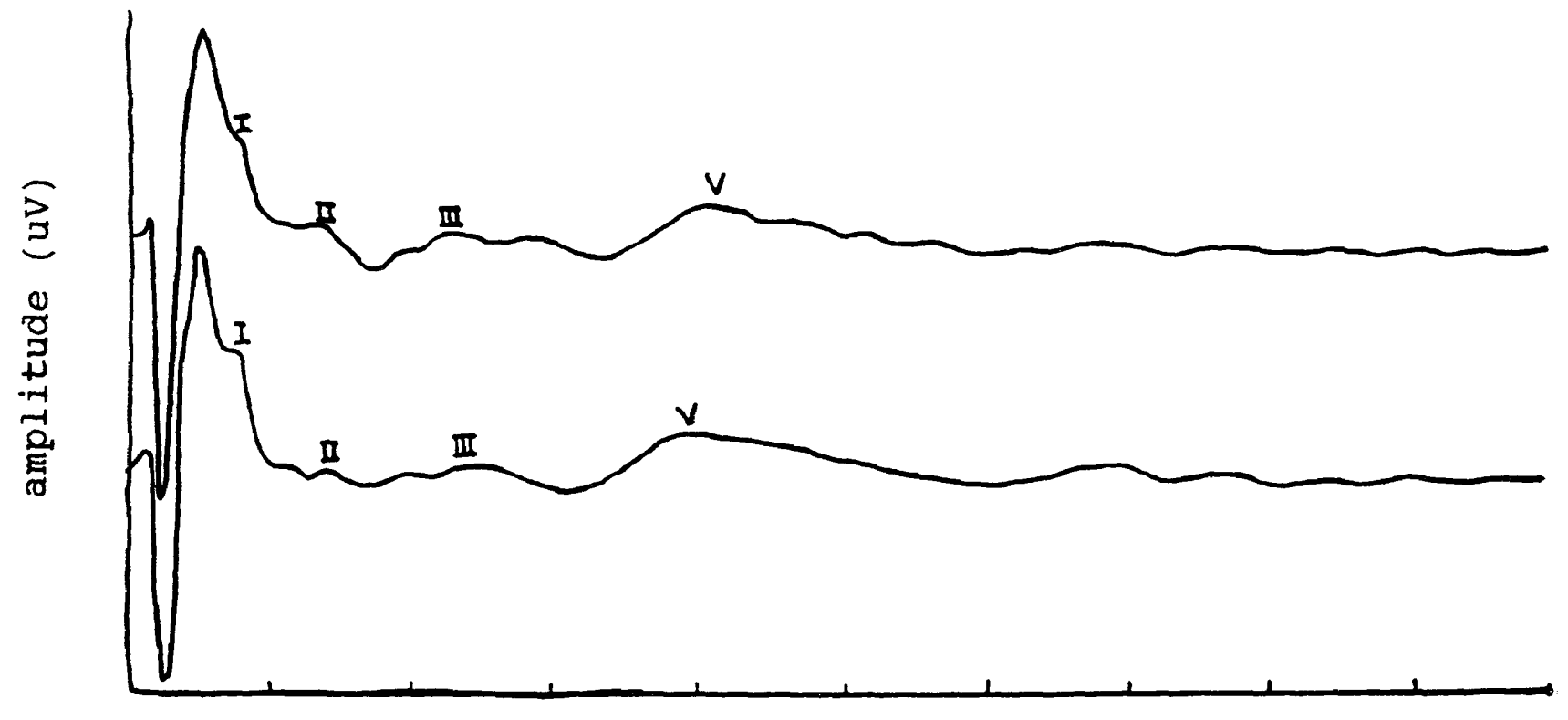

Time (ms) 
can be determined.

The objectives of this project were threefold: a) collect auditory evoked potentials from loggerhead sea turtles to determine threshold of response for both tone bursts and click stimuli, b) test the stimulus rate as presented to the loggerhead for its effect on the I-V interpeak conduction time, and c) test white noise for its ability to mask the stimulus and render the stimulus inaudible. These goals were achieved by laying out a methodology for collecting evoked potentials from sea turtles. 
MATERIALS AND METHODS

Thirty-five healthy loggerhead turtles were used for this study (Table 1). The turtles were caught by poundnets in the Chesapeake Bay: at the mouth of the Potomac River and in Mobjack Bay, at the mouth of the York River. The animals were housed in tanks in a greenhouse facility prior to testing.

\section{Bioelectric measurement}

Auditory evoked potentials may be measured from sea turtles. Turtles were placed in a box to reduce extraneous vibrations. Subdermal electrodes were implanted on either side of the fronto-parietal plate on the dorsal surface of the head. A reference electrode was inserted in the skin immediately behind the skull over the extension of the supraoccipital. Finally, a ground electrode was placed in the inactive skin of the lateral neck (Fig 3).

A computer capable of delivering stimuli and receiving bioelectric activity (Nicolet spirit Portable) was used to measure evoked potentials. This computer contains an 
Table 1. Tag numbers, dates captured and released, weight, and length of the 35 loggerhead turtles used in the three phases of the hearing study.

\begin{tabular}{|c|c|c|c|c|}
\hline $\begin{array}{l}\text { Front } \\
\text { Flipper } \\
\text { Tag\# }\end{array}$ & $\begin{array}{l}\text { Date } \\
\text { Captured }\end{array}$ & $\begin{array}{l}\text { Date } \\
\text { Released }\end{array}$ & $\begin{array}{l}\text { Weight } \\
(\mathrm{Kg} \cdot)\end{array}$ & $\begin{array}{l}\text { Length } \\
\text { (Curved } \\
\text { Notch to } \\
\text { Notch) } \\
\text { (cm) }\end{array}$ \\
\hline $\begin{array}{l}\text { QQM791 } \\
\text { QQM794 } \\
\end{array}$ & $20 \mathrm{JUL} 92$ & 27 MAY 93 & 26.0 & 57.7 \\
\hline $\begin{array}{l}\text { PPX804 } \\
\text { PPX817 } \\
\end{array}$ & 30 JUL 92 & 7 JUN 93 & 69.0 & 83.1 \\
\hline $\begin{array}{l}\text { QQM800 } \\
\text { QQM785 } \\
\end{array}$ & 3 AUG 92 & 27 MAY 93 & 25.0 & 56.4 \\
\hline $\begin{array}{l}\text { QQM7 } 00 \\
\text { QQM701 } \\
\end{array}$ & 17 AUG 92 & 7 JUN 93 & 21.0 & 57.2 \\
\hline $\begin{array}{l}\text { QQM797 } \\
\text { QQM798 } \\
\end{array}$ & 31 AUG 92 & 7 JUN 93 & 35.0 & 67.0 \\
\hline $\begin{array}{l}\text { QQM792 } \\
\text { QQM775 } \\
\end{array}$ & 11 SEP 92 & 21 JUL 93 & 27.0 & 61.1 \\
\hline $\begin{array}{l}\text { QQM605 } \\
\text { QQM606 }\end{array}$ & 15 SEP 92 & 21 JUL 93 & 33.0 & 60.1 \\
\hline $\begin{array}{l}\text { QQM791 } \\
\text { PPX807 } \\
\end{array}$ & 21 SEP 92 & 7 JUN 93 & 24.0 & 56.5 \\
\hline $\begin{array}{l}\mathrm{QQZ} 417 \\
\mathrm{QQZ} 401 \\
\end{array}$ & 2 NOV 92 & 2 JUN 93 & 32.0 & 63.4 \\
\hline $\begin{array}{l}\text { QQZ4 } 18 \\
\text { QQZ4 } 14 \\
\end{array}$ & 5 NOV 92 & 7 JUN 93 & 48.3 & 75.7 \\
\hline $\begin{array}{l}\text { QQZ4 } 407 \\
\text { QQZ4 } 06 \\
\end{array}$ & 26 MAY 93 & 3 AUG 93 & 19.5 & 54.7 \\
\hline $\begin{array}{l}\text { QQZ } 409 \\
\text { QQZ4 } 08 \\
\end{array}$ & 26 MAY 93 & 16 JUN 93 & 31.0 & 63.5 \\
\hline $\begin{array}{l}\text { QQZ4 } 26 \\
Q Q Z 427 \\
\end{array}$ & 4 JUN 93 & 21 JUL 93 & $\mathrm{~N} / \mathrm{A}$ & $\mathrm{N} / \mathrm{A}$ \\
\hline
\end{tabular}




\begin{tabular}{|c|c|c|c|c|}
\hline $\begin{array}{l}\text { Front } \\
\text { Flipper } \\
\text { Tag\# }\end{array}$ & $\begin{array}{l}\text { Date } \\
\text { Captured }\end{array}$ & $\begin{array}{l}\text { Date } \\
\text { Released }\end{array}$ & $\begin{array}{l}\text { Weight } \\
(\mathrm{Kg} \cdot)\end{array}$ & $\begin{array}{l}\text { Length } \\
\text { (Curved } \\
\text { Notch to } \\
\text { Notch) } \\
\text { (cm) }\end{array}$ \\
\hline $\begin{array}{l}\text { QQZ4 } 29 \\
\text { QQZ4 } 30\end{array}$ & 8 JUN 93 & 3 AUG 93 & 14.0 & 48.7 \\
\hline $\begin{array}{l}Q Q Z 437 \\
Q Q Z 438 \\
\end{array}$ & 15 JUN 93 & 10 AUG 93 & 27.0 & 62.0 \\
\hline $\begin{array}{l}\text { QQZ4 } 41 \\
\text { QQC53 }\end{array}$ & 16 JUN 93 & 24 JUL 93 & 24.5 & 55.5 \\
\hline $\begin{array}{l}\text { QQZ4 } 42 \\
\text { QQZ4 } 43 \\
\end{array}$ & 19 JUN 93 & 10 JUL 93 & 55.0 & 78.6 \\
\hline $\begin{array}{l}\text { QQZ4 } 51 \\
\text { QQZ4 } 52 \\
\end{array}$ & 21 JUN 93 & 24 JUL 93 & 28.5 & 61.4 \\
\hline $\begin{array}{l}Q Q Z 455 \\
Q Q Z 456\end{array}$ & 22 JUN 93 & 27 JUL 93 & 99.3 & 97.0 \\
\hline $\begin{array}{l}\text { QQZ4 } 76 \\
\text { QQZ4 } 77 \\
\end{array}$ & 24 JUN 93 & 28 JUL 93 & $\mathrm{~N} / \mathrm{A}$ & 69.0 \\
\hline $\begin{array}{l}\text { QQZ4 } 82 \\
\text { QQZ4 } 83 \\
\end{array}$ & 2 JUL 93 & 8 JUL 93 & 34.8 & 64.3 \\
\hline $\begin{array}{l}Q Q Z 486 \\
Q Q Z 487 \\
\end{array}$ & 6 JUL 93 & 2 AUG 93 & 23.0 & 53.8 \\
\hline $\begin{array}{l}\text { QQZ4 } 92 \\
\text { QQZ493 } \\
\end{array}$ & 13 JUL 93 & 10 AUG 93 & $\mathrm{~N} / \mathrm{A}$ & 69.0 \\
\hline $\begin{array}{l}\text { QQZ496 } \\
\text { QQZ497 } \\
\end{array}$ & 16 JUL 93 & 4 SEP 93 & 26.0 & 58.8 \\
\hline $\begin{array}{l}\text { QQZ500 } \\
\text { QQZ353 } \\
\end{array}$ & 21 JUL 93 & 4 SEP 93 & 23.8 & 54.0 \\
\hline $\begin{array}{l}\text { QQZ354 } \\
\text { QQZ355 } \\
\end{array}$ & 22 JUL 93 & 3 NOV 93 & 35.0 & 64.2 \\
\hline $\begin{array}{l}\text { QQZ4 } 25 \\
\text { QQZ4 } 24 \\
\end{array}$ & 23 JUL 93 & 13 SEP 93 & 19.0 & 53.2 \\
\hline $\begin{array}{l}\text { QQZ3 } 60 \\
\text { QQZ361 } \\
\end{array}$ & 27 JUL 93 & 13 SEP 93 & 21.5 & 56.0 \\
\hline $\begin{array}{l}\text { QQZ362 } \\
\text { QQZ363 }\end{array}$ & 30 JUL 93 & 3 NOV 93 & 32.0 & 63.0 \\
\hline $\begin{array}{l}\text { QQZ364 } \\
\text { QQZ380 }\end{array}$ & 3 AUG 93 & 3 NOV 93 & 30.0 & 58.5 \\
\hline
\end{tabular}




\begin{tabular}{||l|l|l|l|l||}
\hline $\begin{array}{l}\text { Front } \\
\text { Flipper } \\
\text { Tag\# }\end{array}$ & $\begin{array}{l}\text { Date } \\
\text { Captured }\end{array}$ & $\begin{array}{l}\text { Date } \\
\text { Released }\end{array}$ & $\begin{array}{l}\text { Weight } \\
\text { (Kg.) }\end{array}$ & $\begin{array}{l}\text { Length } \\
\text { (Curved } \\
\text { Notch to } \\
\text { Notch) } \\
\text { (cm) }\end{array}$ \\
\hline $\begin{array}{l}\text { QQZ368 } \\
\text { QQZ369 }\end{array}$ & 10 AUG 93 & 12 NOV 93 & 55.0 & 77.1 \\
\hline $\begin{array}{l}\text { QQM764 } \\
\text { QQM772 }\end{array}$ & 10 AUG 93 & 3 NOV 93 & 32.5 & 64.9 \\
\hline $\begin{array}{l}\text { SSB801 } \\
\text { SSB802 }\end{array}$ & 18 MAY 94 & 7 JUN 94 & 27.0 & 58.3 \\
\hline $\begin{array}{l}\text { SSB805 } \\
\text { SSB806 }\end{array}$ & 19 MAY 94 & 7 JUN 94 & 14.0 & 49.7 \\
\hline $\begin{array}{l}\text { SSB827 } \\
\text { SSB818 }\end{array}$ & 25 MAY 94 & 7 JUN 94 & 23.0 & 54.8 \\
\hline
\end{tabular}


Figure 3. Placement of the electrodes and mechanical vibrator on the head of the loggerhead sea turtle when collecting auditory evoked potentials. 


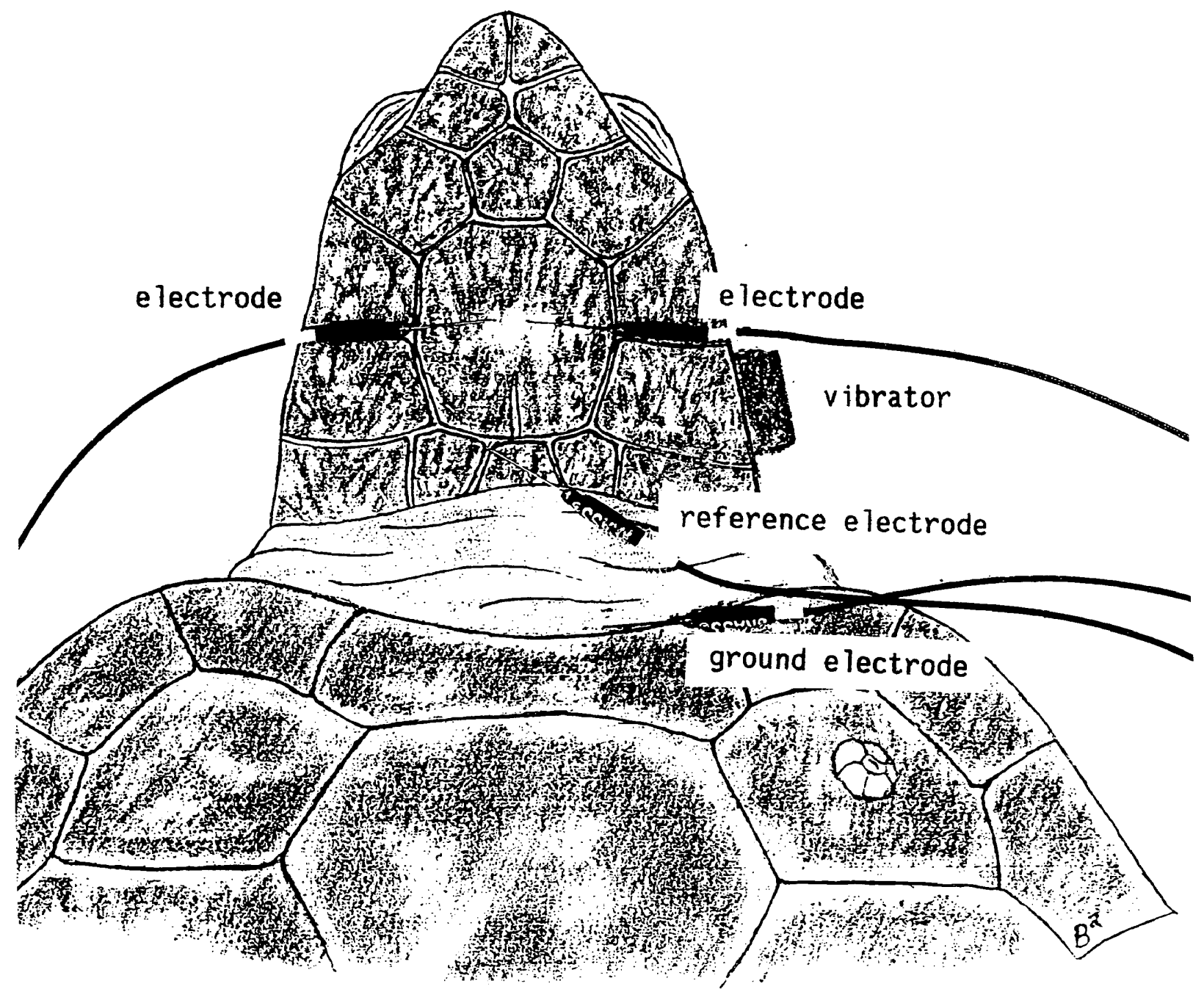


interface for the electrodes. Two channels, left and right, of electroencephalographic (EEG) activity were amplified (x20k) and filtered $(5-3000 \mathrm{~Hz})$ by the computer. Bioelectric activity was time-locked to the delivery of the stimulus (mechanical vibrator) secured over the eardrum and thus recorded by the computer at the same rate as the stimulus. Evoked potentials were extracted from the EEG by repeating and averaging single responses. At least 500 responses were averaged for each trial. Averaging reduces the components of the EEG unrelated to the stimulus (such as muscle contractions and other extraneous biological activity) so that responses can be clearly distinguished (Spehlmann, 1985). A time window of 10 milliseconds for collecting EEG activity was set on the computer. The stimulus used was either a broadband click composed of a frequency spectrum from $250-1250 \mathrm{~Hz}$ or tone bursts with a central frequency at $250,500,750$, or $1000 \mathrm{~Hz}$. The actual frequency was obtained by coupling the vibrator to a piezoelectric film sensor and measuring the energy with a real time spectral analyzer (Appendix).

\section{Threshold measurements}

All turtles were used in the threshold experiments. Stimuli of either clicks composed of a broadband frequency or tone bursts were delivered through the bone vibrator strapped to the tympanum. The intensity of the stimulus was manipulated, ranging from -36 to $7 \mathrm{~dB}$ [re: one gravity 
unit (g)]. An accelerometer was used to measure the intensity of the stimulus, and acceleration of the mechanical vibrator was obtained.

Measurement of the stimulation of the auditory nervous system with the use of this bone vibrator was through the examination of the EEG readouts produced by the computer. A positive wave at about 4.5 milliseconds (peak V) was used as an index for determining threshold. This wave decreased in amplitude and increased in latency as the stimulus intensity decreased. The lowest intensity at which peak $\mathrm{V}$ was identifiable by subjective observation was termed the threshold (Fig 4).

Measurements of threshold of hearing for clicks were also converted to sound pressure level (SPL), a reference level commonly used by researchers. Evoked potentials were measured in the manner described above. However, for this test, the stimulus was presented by a loudspeaker positioned above the turtle's head. The click intensity was measured with an SPL meter held between the loudspeaker and the turtle's head. Threshold was measured and compared to the threshold obtained from the bone vibrator.

\section{Repetition rate}

Nineteen of the 35 loggerheads were used in the repetition rate experiments. The broadband click used in the threshold study was utilized as the stimulus (with a fixed intensity of $6 \mathrm{~dB}$ re: 1 gravity unit) to examine the 
Figure 4. Representative drawing of the EEG waves measured from a loggerhead sea turtle while testing for hearing threshold. Peak $\mathrm{V}$ is the index peak used to determine threshold. 


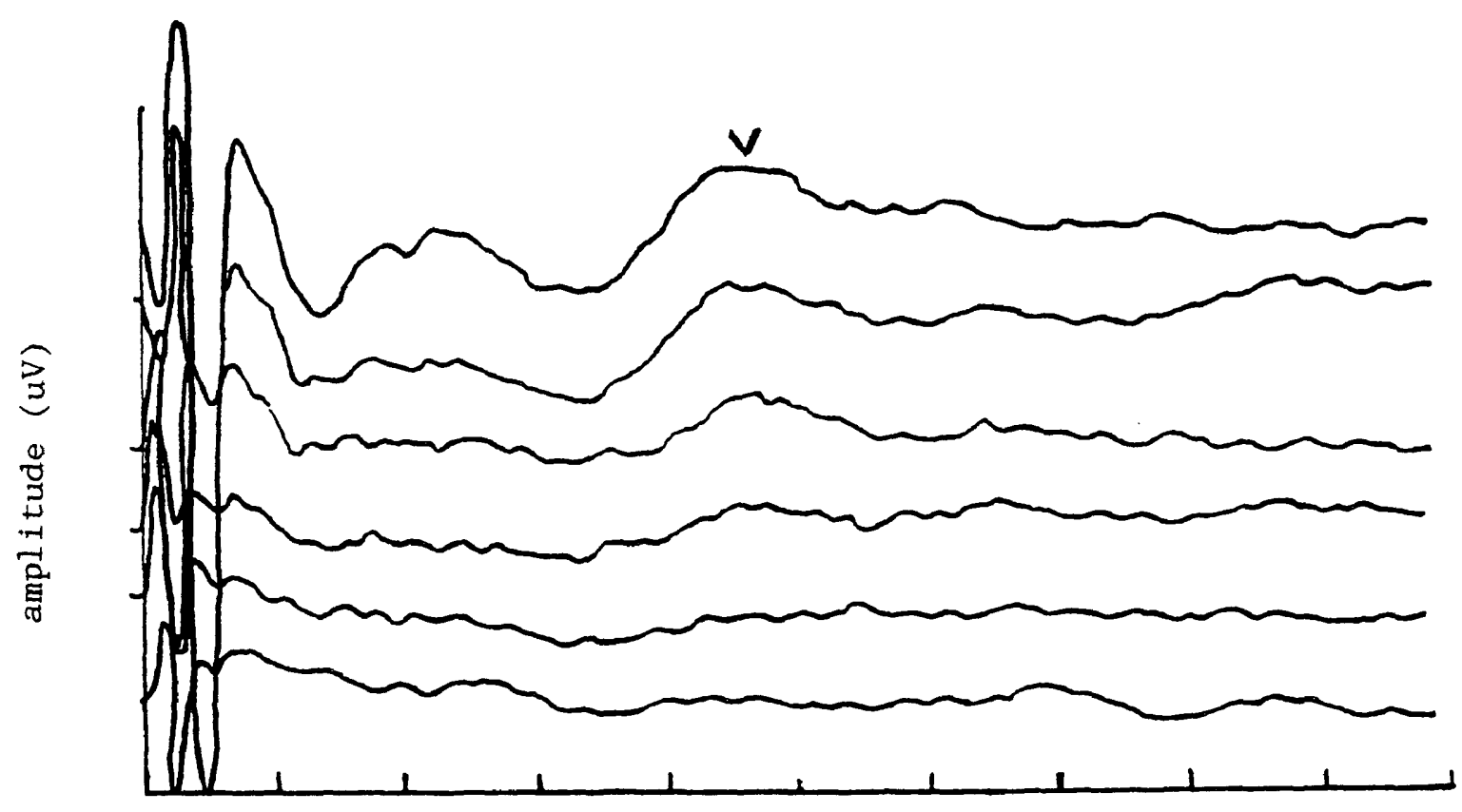

Time (ms) 
response to the change in the repetition rate. The rate of the click was then systematically varied from 1.1 to 90.1 clicks per seconds. Interpeak latency between peak I and peak $V$ was computed as the conduction time between the peaks (Fig 5). Interpeak latencies were examined for dependence on the rate of the stimulus by performing a regression for each of the 19 turtles (Zar, 1984).

\section{Masking Experiment}

Fifteen of the 35 loggerheads were used in the stimulus masking experiments. White noise was incorporated into the stimulus so that both noise and click were delivered to the same ear. The click intensity remained constant at a superthreshold level and was determined for each turtle individually. Repetition rate of the stimulus was fixed at 10.1 clicks/s. The white noise was varied from $20 \mathrm{~dB}$ below the click intensity to $10 \mathrm{~dB}$ above the click intensity (Fig 6). Signal and noise levels for the last point at which the turtle could distinguish the stimulus were measured and signal to noise ratios were determined. In decibels, the signal to noise ratio is equal to the signal energy minus the white noise energy (Yost and Nielsen, 1977). 
Figure 5. An example of waves collected from a loggerhead sea turtle while examining for the effect of stimulus rate on the latencies of peak I and V. Rates tested were 1.1, $10.1,20.1,30.1,40.1,50.1,60.1,70.1,80.1$, and 90.1 respectively. 


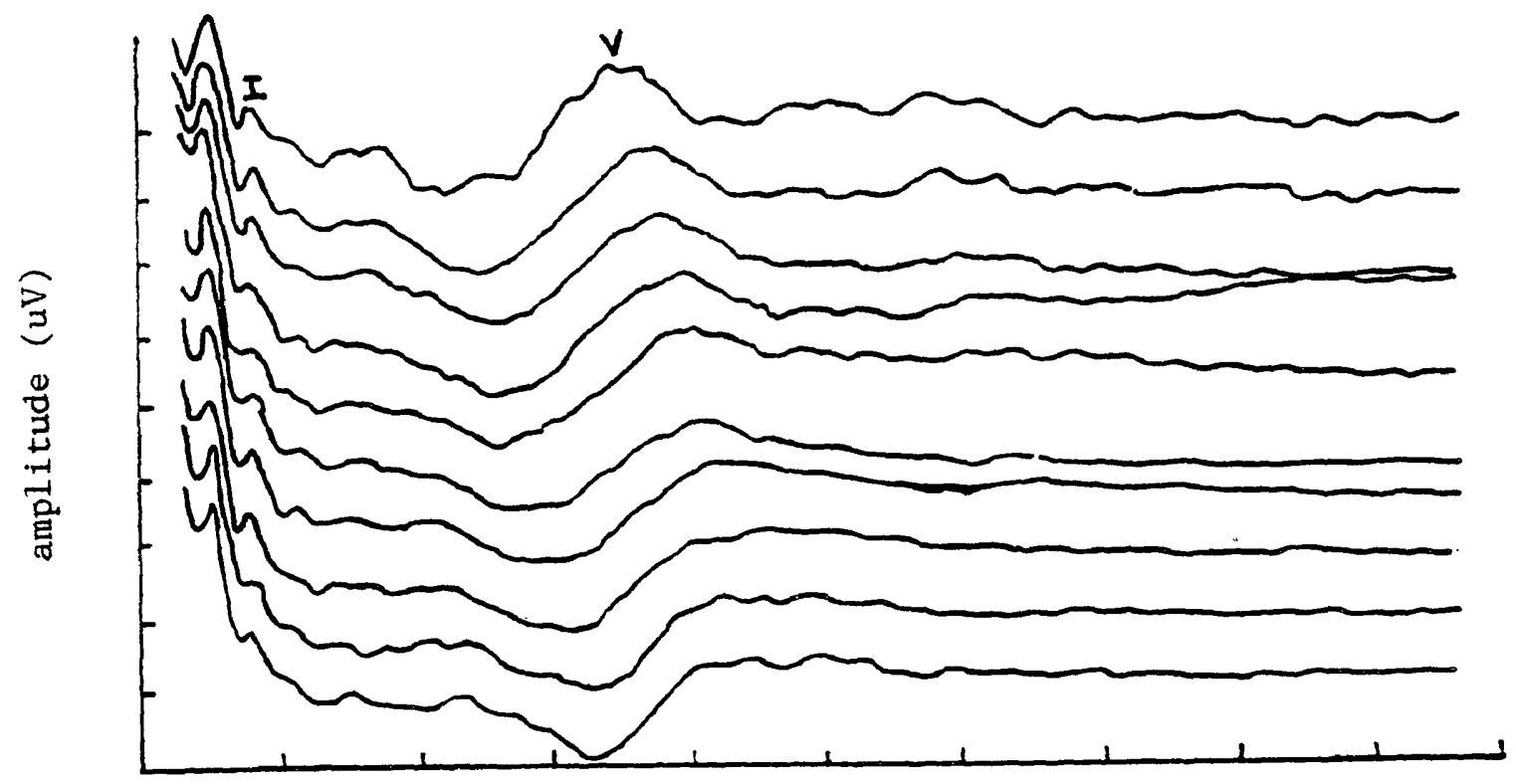

Time (ms) 
Figure 6. Representative evoked potential waves collected when white noise and broadband click were used as the stimuli for a loggerhead sea turtle. The click intensity remained constant and noise intensity varied from $20 \mathrm{~dB}$ below to $10 \mathrm{~dB}$ above the click intensity. 


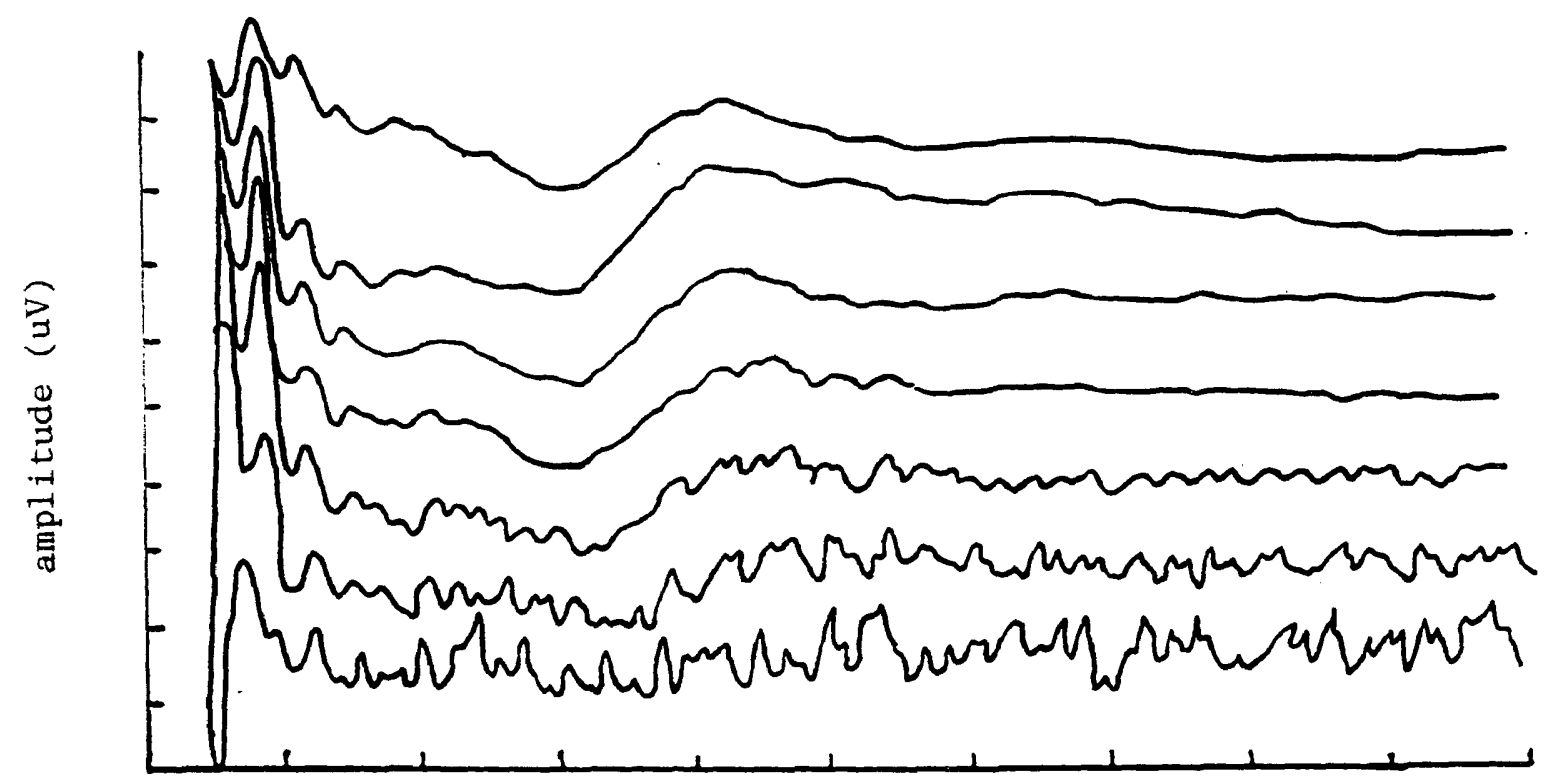

Time (ms) 
RESULTS

The broadband click produced very clear and repeatable auditory responses. The mean intensity threshold for the 35 turtles was $-10.8 \mathrm{~dB}$ re: 1 gravity unit with a standard deviation of $4.6 \mathrm{~dB}$. It was possible to convert these data into sound pressure level with a resulting mean of $8.5 \mathrm{~dB}$ re: 1 dyne $/ \mathrm{cm}^{2}$ with a standard deviation of $5.5 \mathrm{~dB}$ (Table 2).

There were several difficulties in recording the auditory evoked potentials from tone burst stimuli. Readable and repeatable responses were extracted from only six of the turtles tested. Furthermore, it was impossible, with the available equipment, to convert the decibel levels of tones into sound pressure levels. Thus, the evoked potentials (Figures 7-12) were due to vibratory stimulation and calibrated in decibels relative to acceleration (gravity). The maximum sensitivity was in the low frequency region of 250-1000 $\mathrm{Hz}$. The decline in sensitivity was great after $1000 \mathrm{~Hz}$ and beyond the recording capabilities of the equipment. The most sensitive threshold for these five turtles was found to be at $250 \mathrm{~Hz}$ with a mean intensity 
Table 2. Threshold level of hearing with a click stimulus for loggerhead sea turtles calibrated in both acceleration and sound pressure level.

\begin{tabular}{|c|c|c|}
\hline $\begin{array}{l}\text { Front Flipper } \\
\text { Tag Numbers }\end{array}$ & $\begin{array}{c}\text { Threshold } \\
\text { dB re: } 1 \\
\text { gravity }\end{array}$ & $\begin{array}{c}\text { Threshold } \\
\mathrm{dB}: 1 \text { dyne } / \mathrm{cm}^{2}\end{array}$ \\
\hline QQM700 / QQM701 & -16.5 & 1.7 \\
\hline QQM791/QQM794 & -16.5 & 1.7 \\
\hline QQM792 / QQM775 & $-12 \cdot 5$ & 6.5 \\
\hline QQM791/PPX807 & -17.5 & 0.5 \\
\hline QQM797 / QQM798 & -9.5 & 10.1 \\
\hline QQM605/QQM606 & -14.5 & 4.1 \\
\hline QQM800/QQM785 & $-16 \cdot 5$ & 1.7 \\
\hline QQZ4 17 / QQZ4 01 & $-12 \cdot 5$ & 6.5 \\
\hline QQZ4 $18 / \mathrm{QQZ} 414$ & -7.5 & 12.5 \\
\hline PPX804 / PPX8 17 & -1.5 & 19.6 \\
\hline QQZ409/QQZ408 & -7.5 & 12.5 \\
\hline QQZ426/QQZ427 & -5.5 & 14.9 \\
\hline QQZ4 $07 / Q Q Z 406$ & -10.5 & 8.9 \\
\hline QQZ4 $29 / \mathrm{QQZ} 430$ & $-14 \cdot 5$ & 4.1 \\
\hline QQZ4 $41 / \mathrm{QQC5} 30$ & -7.5 & 12.5 \\
\hline QQZ4 $37 / Q Q Z 438$ & $-14 \cdot 5$ & 4.4 \\
\hline QQZ4 42 / QQZ4 43 & -7.5 & 12.5 \\
\hline QQZ451/QQZ452 & -6.5 & 14.9 \\
\hline QQZ455/QQZ456 & -1.5 & 19.5 \\
\hline QQZ476/QQZ477 & $-7 \cdot 5$ & 12.5 \\
\hline QQZ4 82 / QQZ483 & -9.5 & 10.1 \\
\hline QQZ4 $86 / Q Q Z 487$ & -9.5 & 10.1 \\
\hline
\end{tabular}




\begin{tabular}{||l|c|c||}
\hline $\begin{array}{l}\text { Front Flipper } \\
\text { Tag Numbers }\end{array}$ & $\begin{array}{c}\text { Threshold } \\
\text { dB re: } 1 \\
\text { gravity }\end{array}$ & $\begin{array}{c}\text { Threshold } \\
\text { dB: } 1 \text { dyne/cm }\end{array}$ \\
\hline QQZ492/QQZ493 & -12.5 & 6.5 \\
\hline QQZ500/QQZ353 & -19.5 & -1.8 \\
\hline QQZ496/QQZ497 & -7.5 & 12.5 \\
\hline QQZ360/QQZ361 & -15.5 & 2.9 \\
\hline QQZ362/QQZ363 & -12.5 & 6.5 \\
\hline QQZ425/QQZ424 & -12.5 & 6.5 \\
\hline QQZ364/QQZ380 & -9.5 & 10.1 \\
\hline QQZ354/QQZ355 & -7.5 & 12.5 \\
\hline QQM764/QQM772 & -12.5 & 10.1 \\
\hline QQZ368/QQZ369 & -9.5 & 18.4 \\
\hline SSB801/SSB802 & -2.5 & 0.5 \\
\hline SSB805/SSB806 & -17.5 & 6.5 \\
\hline SSB827/SSB818 & -12.5 & $8.5 \pm 5.5$ \\
\hline $\begin{array}{l}\text { Mean } \pm \text { Standard } \\
\text { deviation }\end{array}$ & $-10.8 \pm 4.6$ & \\
\hline
\end{tabular}


Figure 7. Threshold levels collected from turtle QQM800/QQM785 for 250, 500, 750, and $1000 \mathrm{~Hz}$ frequency levels. The intensity level is due to vibratory stimulation and is calibrated in decibels relative to acceleration. 
Threshold Levels for Turtle QQM800/QQM785

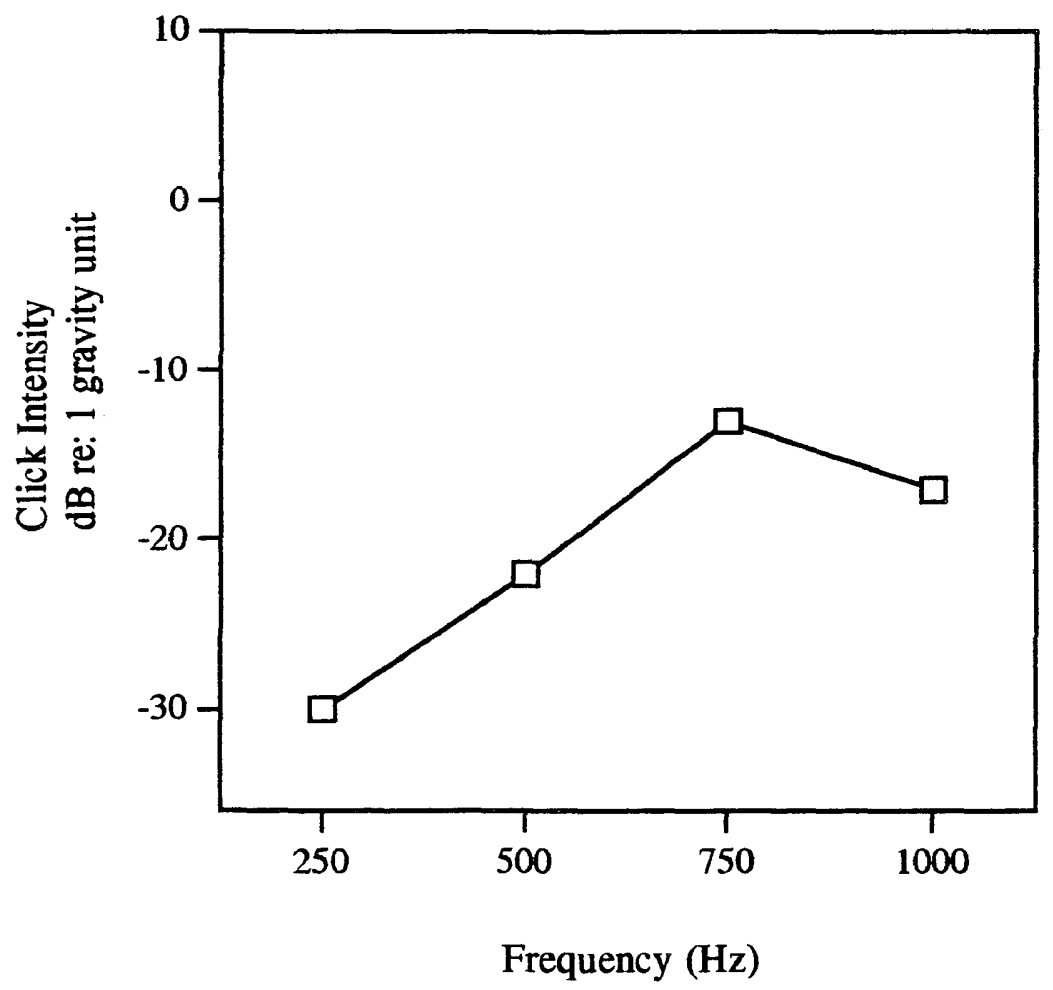


Figure 8. Threshold levels collected from turtle QQZ418/QQZ414 for $250,500,750$, and $1000 \mathrm{~Hz}$ frequency levels. The intensity level is due to vibratory stimulation and is calibrated in decibels relative to acceleration. 
Threshold Levels for Turtle QQZ418/QQZ414

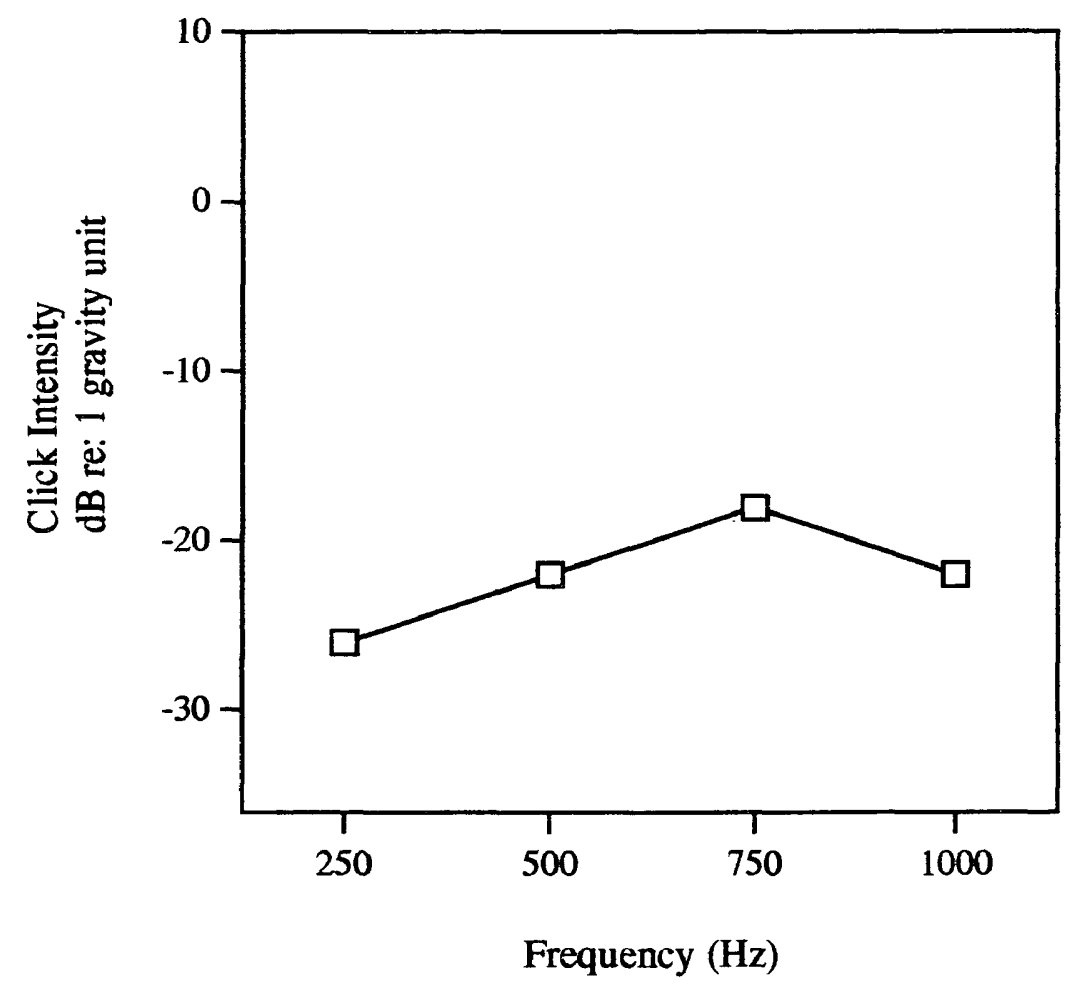


Figure 9. Threshold levels collected from turtle SSB805/SSB806 for 250, 500, 750, and $1000 \mathrm{~Hz}$ frequency levels. The intensity level is due to vibratory stimulation and is calibrated in decibels relative to acceleration. 
Threshold Levels for Turtle SSB805/SSB806

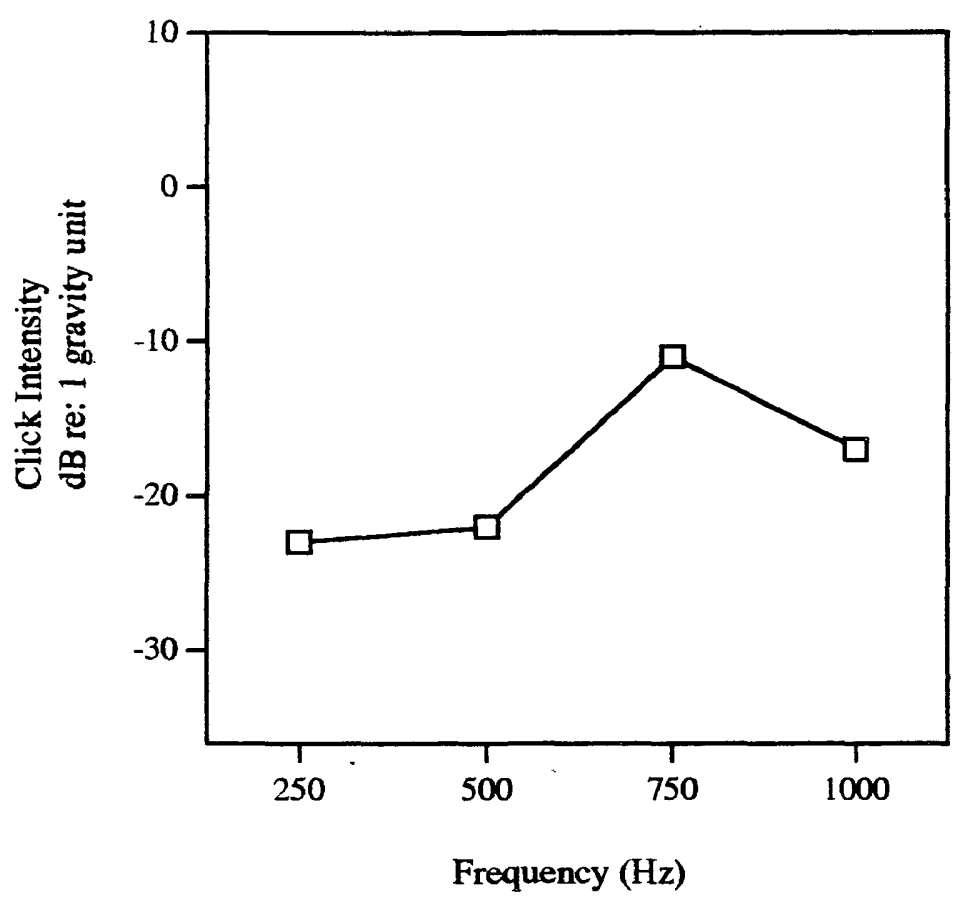


Figure 10. Threshold levels collected from turtle PPX804/PPX817 for 250, 500, 750, and $1000 \mathrm{~Hz}$ frequency levels. The intensity level is due to vibratory stimulation and is calibrated in decibels relative to acceleration. 
Threshold Levels for Turtle PPX804/PPX817

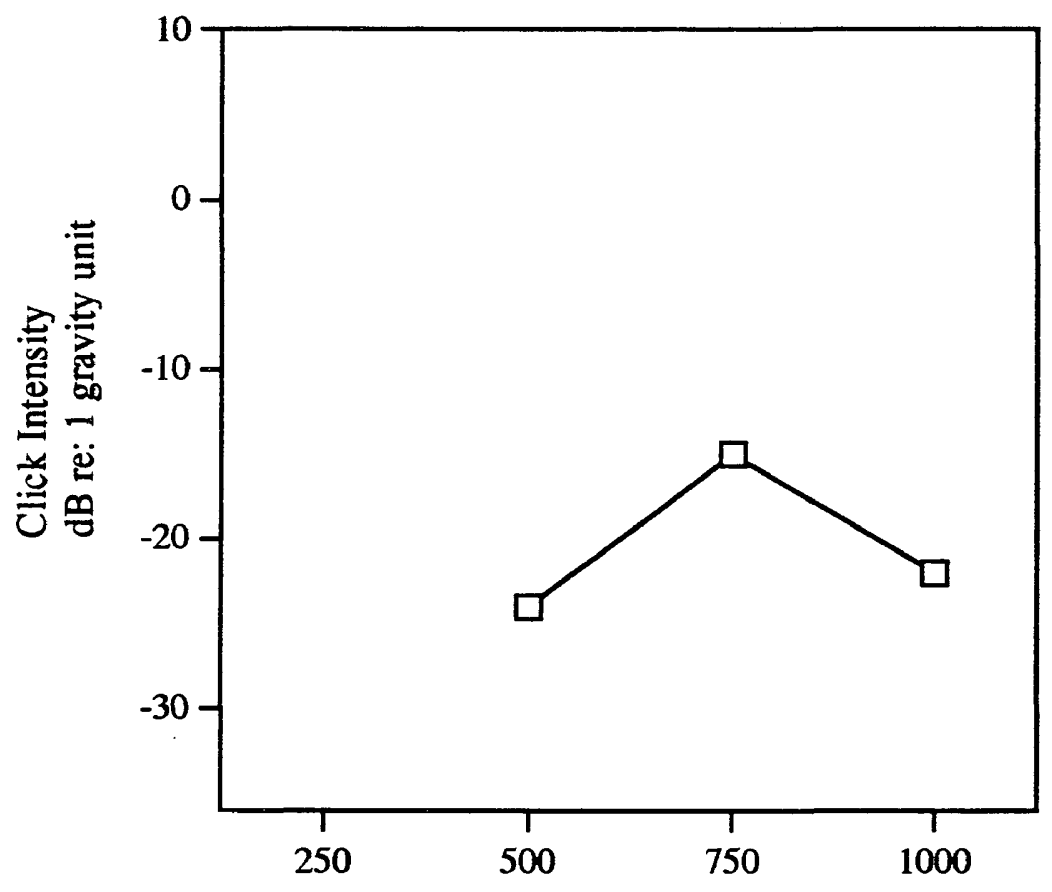

Frequency (Hz) 
Figure 11. Threshold levels collected from turtle QQM791/PPX 807 for 250, 500, 750, and $1000 \mathrm{~Hz}$ frequency levels. The intensity level is due to vibratory stimulation and is calibrated in decibels relative to acceleration. 
Threshold Levels for Turtle QQM791/PPX807

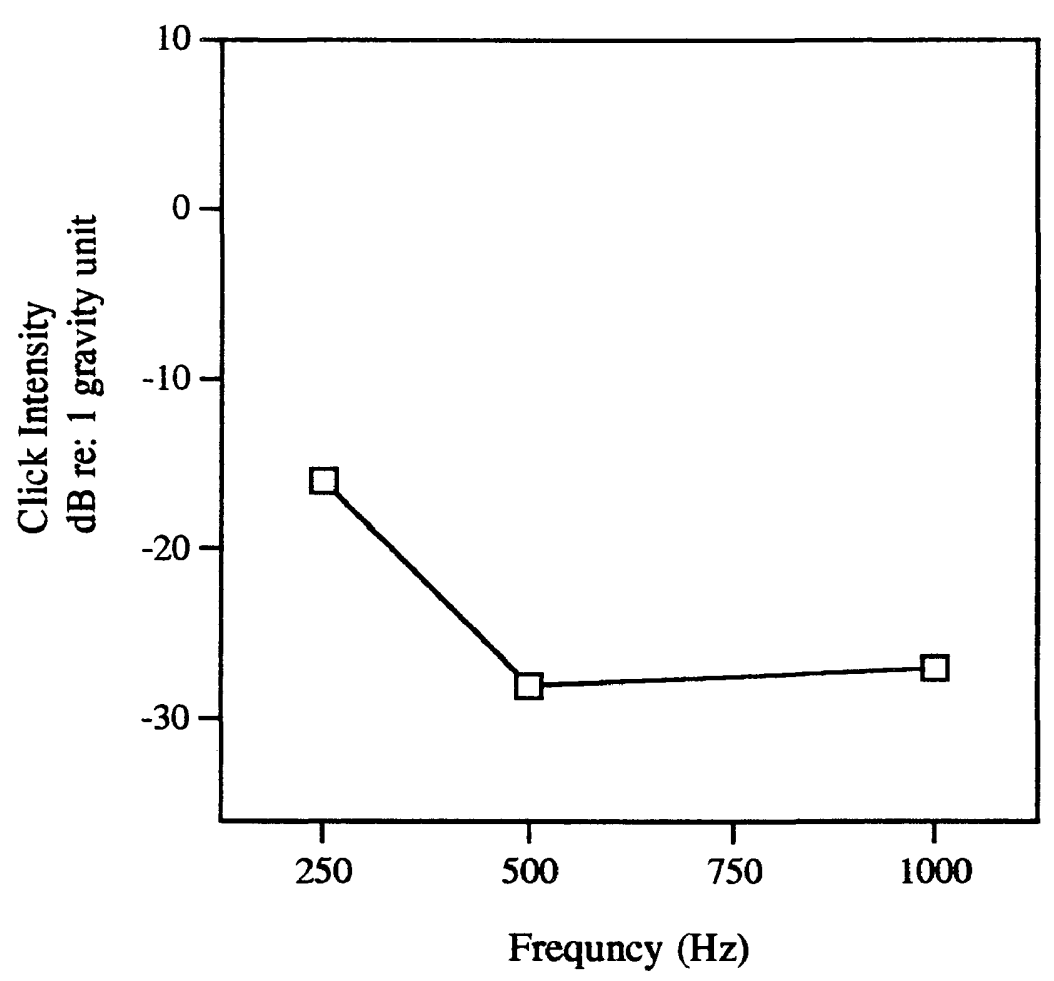


Figure 12. Threshold levels collected from turtle QQZ417/QQZ401 for $250,500,750$, and $1000 \mathrm{~Hz}$ frequency levels. The intensity level is due to vibratory stimulation and is calibrated in decibels relative to acceleration. 
Threshold Levels for Turtle QQZ417/QQZ401

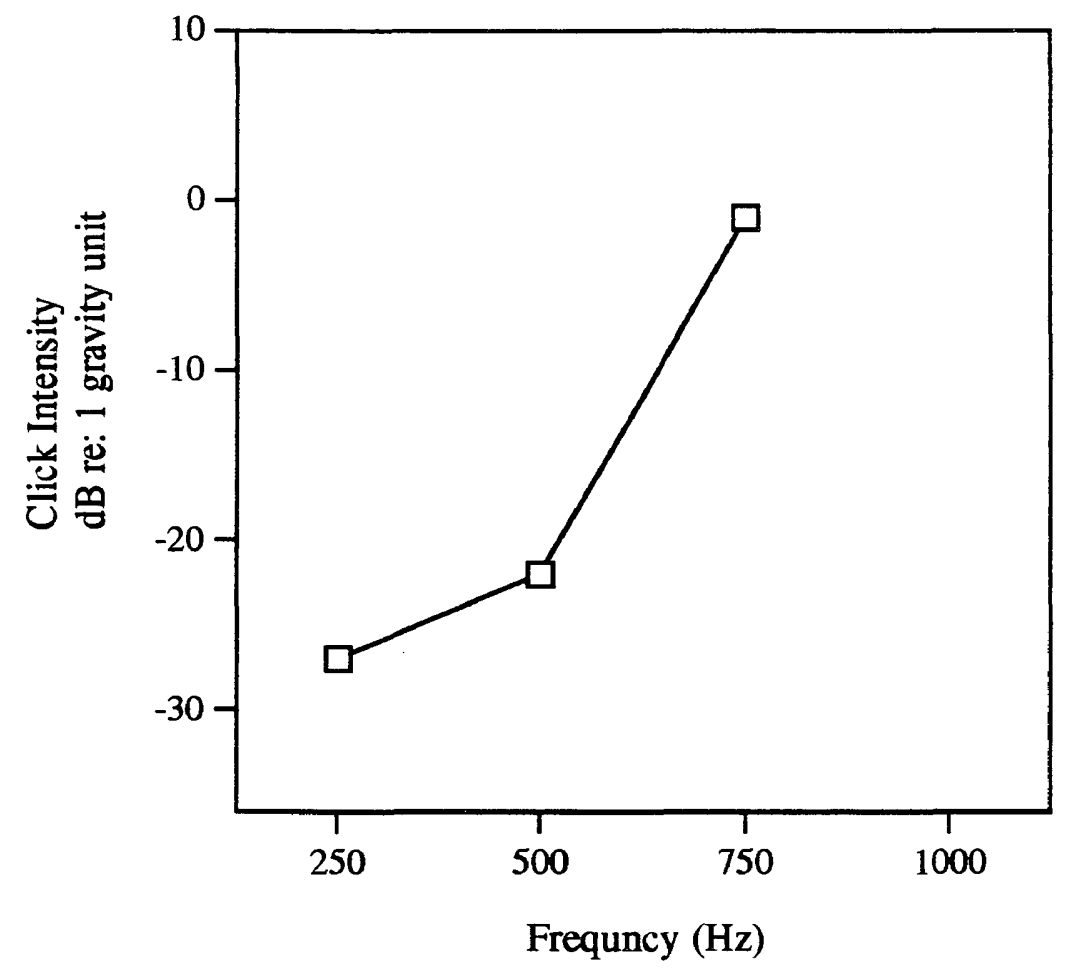


threshold of $-24.4 \mathrm{~dB}$ (Table 3 ).

In the repetition rate experiments, interpeak latencies for peak I and peak $V$ were significantly dependant on rate (Table 4 and 5). An increase in latency was observed with the increase of stimulus rate.

In the masking experiment, stimulus intensity ranged from -2.5 to $7.5 \mathrm{dBs}$. White noise required to mask these stimuli ranged from 6 to $16 \mathrm{dBs.} \mathrm{Stimulus} \mathrm{to} \mathrm{noise} \mathrm{ratios}$ ranged from -3.5 to $-8.5 \mathrm{~dB}(\mathrm{x}=-5.2 \pm 2.4)$ (Table 6). 
Table 3. Threshold data for six loggerhead turtles using tone burst with frequencies centered around $250 \mathrm{~Hz}, 500 \mathrm{~Hz}$, $750 \mathrm{~Hz}$, and $1000 \mathrm{~Hz}$.

\begin{tabular}{||l|c|c|c|c||}
\hline $\begin{array}{l}\text { Front } \\
\text { Flipper } \\
\text { Tag\# }\end{array}$ & $250 \mathrm{~Hz}$ & $500 \mathrm{~Hz}$ & $750 \mathrm{~Hz}$ & $1000 \mathrm{~Hz}$ \\
\hline $\begin{array}{l}\text { QQM800 } \\
\text { QQM785 }\end{array}$ & -30 & -22 & -13 & -17 \\
\hline $\begin{array}{l}\text { QQZ418 } \\
\text { QQZ414 }\end{array}$ & -26 & -22 & -18 & -22 \\
\hline $\begin{array}{l}\text { SSB805 } \\
\text { SSB806 }\end{array}$ & -23 & -22 & -11 & -17 \\
\hline $\begin{array}{l}\text { PPX804 } \\
\text { PPX817 }\end{array}$ & $\mathrm{N} / \mathrm{A}$ & -24 & -15 & -22 \\
\hline $\begin{array}{l}\text { QQM791 } \\
\text { PPX807 }\end{array}$ & -16 & -28 & $\mathrm{~N} / \mathrm{A}$ & -27 \\
\hline $\begin{array}{l}\text { QQZ417 } \\
\text { QQZ401 }\end{array}$ & -27 & -22 & -1 & $\mathrm{~N} / \mathrm{A}$ \\
\hline \hline $\begin{array}{l}\text { Mean } \\
\text { standard } \\
\text { deviation }\end{array}$ & $-24.4 \pm$ & $-23.3 \pm$ & $-11.6 \pm$ & 6.5 \\
\hline
\end{tabular}


Table 4. Latencies between peak $I$ and peak $V$ collected from the auditory evoked potentials of 19 loggerhead sea turtles. The stimulus was a broadband click and the stimulus rate varied from 1.1-90.1 clicks per second.

\begin{tabular}{|c|c|c|}
\hline $\begin{array}{l}\text { Front Flipper Tag } \\
\text { Numbers }\end{array}$ & $\begin{array}{c}\text { Rate } \\
\text { (clicks/sec) }\end{array}$ & $\begin{array}{l}\text { Latency } \\
\text { (ms) }\end{array}$ \\
\hline \multirow[t]{10}{*}{ QQM792/QQM775 } & 1.1 & 3.02 \\
\hline & 10.1 & 3.22 \\
\hline & 20.1 & 3.36 \\
\hline & 30.1 & 3.56 \\
\hline & 40.1 & 3.64 \\
\hline & 50.1 & 3.76 \\
\hline & 60.1 & 3.76 \\
\hline & 70.1 & 4.16 \\
\hline & 80.1 & 4.18 \\
\hline & 90.1 & 4.22 \\
\hline \multirow[t]{9}{*}{ QQM791/QQM794 } & 1.1 & 2.76 \\
\hline & 10.1 & 2.82 \\
\hline & 20.1 & 2.96 \\
\hline & 30.1 & 2.94 \\
\hline & 40.1 & 3.08 \\
\hline & 50.1 & 3.14 \\
\hline & 60.1 & 3.40 \\
\hline & 70.1 & 3.74 \\
\hline & 80.1 & 4.84 \\
\hline
\end{tabular}




\begin{tabular}{|c|c|c|}
\hline $\begin{array}{l}\text { Front Flipper Tag } \\
\text { Numbers }\end{array}$ & $\begin{array}{c}\text { Rate } \\
\text { (clicks/sec) } \\
\end{array}$ & $\begin{array}{c}\text { Latency } \\
\text { (ms) }\end{array}$ \\
\hline & 90.1 & 3.94 \\
\hline \multirow[t]{10}{*}{ QQM797/ QQM798 } & 1.1 & 3.36 \\
\hline & 10.1 & 3.68 \\
\hline & 20.1 & 3.88 \\
\hline & 30.1 & 3.98 \\
\hline & 40.1 & 4.34 \\
\hline & 50.1 & 4.62 \\
\hline & 60.1 & 4.88 \\
\hline & 70.1 & 4.9 \\
\hline & 80.1 & 4.98 \\
\hline & 90.1 & 5.16 \\
\hline \multirow[t]{10}{*}{ QQM605/QQM606 } & 1.1 & 2.92 \\
\hline & 10.1 & 3.16 \\
\hline & 20.1 & 3.26 \\
\hline & 30.1 & 3.48 \\
\hline & 40.1 & 3.36 \\
\hline & 50.1 & 3.72 \\
\hline & 60.1 & 3.74 \\
\hline & 70.1 & 3.70 \\
\hline & 80.1 & 3.94 \\
\hline & 90.1 & 4.06 \\
\hline \multirow[t]{9}{*}{ QQM800/QQM785 } & 1.1 & 3.16 \\
\hline & 10.1 & 3.46 \\
\hline & 20.1 & 3.56 \\
\hline & 30.1 & 3.66 \\
\hline & 40.1 & 3.78 \\
\hline & 50.1 & 3.86 \\
\hline & 60.1 & 4.20 \\
\hline & 70.1 & 4.30 \\
\hline & 80.1 & 4.38 \\
\hline
\end{tabular}




\begin{tabular}{|c|c|c|}
\hline $\begin{array}{l}\text { Front Flipper Tag } \\
\text { Numbers }\end{array}$ & $\begin{array}{c}\text { Rate } \\
\text { (clicks/sec) }\end{array}$ & $\begin{array}{c}\text { Latency } \\
\text { (ms) }\end{array}$ \\
\hline & 90.1 & 4.44 \\
\hline \multirow[t]{10}{*}{ QQZ4 $17 / Q Q 2401$} & 1.1 & 3.04 \\
\hline & 10.1 & 3.28 \\
\hline & 20.1 & 3.44 \\
\hline & 30.1 & 3.72 \\
\hline & 40.1 & 3.88 \\
\hline & 50.1 & 3.92 \\
\hline & 60.1 & 4.08 \\
\hline & 70.1 & 4.16 \\
\hline & 80.1 & 4.12 \\
\hline & 90.1 & 4.12 \\
\hline \multirow[t]{10}{*}{ QQZ409/QQZ408 } & 1.1 & 3.70 \\
\hline & 10.1 & 3.72 \\
\hline & 20.1 & 3.96 \\
\hline & 30.1 & 4.04 \\
\hline & 40.1 & 4.10 \\
\hline & 50.1 & 4.18 \\
\hline & 60.1 & 4.22 \\
\hline & 70.1 & 4.46 \\
\hline & 80.1 & 5.02 \\
\hline & 90.1 & 4.82 \\
\hline \multirow[t]{9}{*}{ QQZ4 $26 / Q Q Z 427$} & 1.1 & 3.08 \\
\hline & 10.1 & 3.46 \\
\hline & 20.1 & 3.60 \\
\hline & 30.1 & 3.74 \\
\hline & 40.1 & 3.70 \\
\hline & 50.1 & 3.76 \\
\hline & 60.1 & 3.78 \\
\hline & 70.1 & 3.94 \\
\hline & 80.1 & 4.08 \\
\hline
\end{tabular}




\begin{tabular}{|c|c|c|}
\hline $\begin{array}{l}\text { Front Flipper Tag } \\
\text { Numbers }\end{array}$ & $\begin{array}{c}\text { Rate } \\
\text { (clicks/sec) }\end{array}$ & $\begin{array}{l}\text { Latency } \\
\text { (ms) }\end{array}$ \\
\hline & 90.1 & 4.44 \\
\hline \multirow[t]{8}{*}{$\mathrm{QQZ4} 07 / \mathrm{QQZ} 406$} & 1.1 & 3.44 \\
\hline & 10.1 & 3.54 \\
\hline & 20.1 & 3.82 \\
\hline & 30.1 & 3.96 \\
\hline & 40.1 & 4.04 \\
\hline & 50.1 & 3.96 \\
\hline & 60.1 & 4.04 \\
\hline & 70.1 & 4.04 \\
\hline \multirow[t]{2}{*}{. } & 80.1 & 4.18 \\
\hline & 90.1 & 4.52 \\
\hline \multirow[t]{10}{*}{$\mathrm{QQZ429/QQZ430}$} & 1.1 & 2.92 \\
\hline & 10.1 & 3.10 \\
\hline & 20.1 & 3.20 \\
\hline & 30.1 & 3.36 \\
\hline & 40.1 & 3.36 \\
\hline & 50.1 & 3.56 \\
\hline & 60.1 & 3.58 \\
\hline & 70.1 & 3.72 \\
\hline & 80.1 & 3.78 \\
\hline & 90.1 & 3.94 \\
\hline \multirow[t]{9}{*}{ QQZ441/QQC530 } & 1.1 & 3.50 \\
\hline & 10.1 & 3.52 \\
\hline & 20.1 & 3.70 \\
\hline & 30.1 & 3.88 \\
\hline & 40.1 & 4.04 \\
\hline & 50.1 & 4.10 \\
\hline & 60.1 & 4.24 \\
\hline & 70.1 & 4.28 \\
\hline & 80.1 & 4.24 \\
\hline
\end{tabular}




\begin{tabular}{|c|c|c|}
\hline $\begin{array}{l}\text { Front Flipper Tag } \\
\text { Numbers }\end{array}$ & $\begin{array}{c}\text { Rate } \\
\text { (clicks/sec) }\end{array}$ & $\begin{array}{l}\text { Latency } \\
(\mathrm{ms})\end{array}$ \\
\hline & 90.1 & 4.28 \\
\hline \multirow[t]{10}{*}{$\mathrm{QQZ4} 37 / \mathrm{QQZ} 438$} & 1.1 & 3.00 \\
\hline & 10.1 & 3.42 \\
\hline & 20.1 & 3.42 \\
\hline & 30.1 & 3.94 \\
\hline & 40.1 & 4.00 \\
\hline & 50.1 & 4.14 \\
\hline & 60.1 & 4.18 \\
\hline & 70.1 & 4.32 \\
\hline & 80.1 & 4.36 \\
\hline & 90.1 & 4.58 \\
\hline \multirow[t]{10}{*}{$\mathrm{QQZ4} 42 / \mathrm{QQZ} 443$} & 1.1 & 3.04 \\
\hline & 10.1 & 3.10 \\
\hline & 20.1 & 3.16 \\
\hline & 30.1 & 3.22 \\
\hline & 40.1 & 3.26 \\
\hline & 50.1 & 3.40 \\
\hline & 60.1 & 3.46 \\
\hline & 70.1 & 3.58 \\
\hline & 80.1 & 4.16 \\
\hline & 90.1 & 4.22 \\
\hline \multirow[t]{9}{*}{ QQZ482/QQZ483 } & 1.1 & 2.88 \\
\hline & 10.1 & 2.74 \\
\hline & 20.1 & 2.90 \\
\hline & 30.1 & 2.94 \\
\hline & 40.1 & 3.00 \\
\hline & 50.1 & 2.96 \\
\hline & 60.1 & 3.04 \\
\hline & 70.1 & 3.12 \\
\hline & 80.1 & 3.16 \\
\hline
\end{tabular}




\begin{tabular}{|c|c|c|}
\hline $\begin{array}{l}\text { Front Flipper Tag } \\
\text { Numbers }\end{array}$ & $\begin{array}{c}\text { Rate } \\
\text { (clicks/sec) }\end{array}$ & $\begin{array}{c}\text { Latency } \\
(\mathrm{ms})\end{array}$ \\
\hline & 90.1 & 3.12 \\
\hline \multirow[t]{10}{*}{$\mathrm{QQZ} 486 / \mathrm{QQZ} 487$} & 1.1 & 2.28 \\
\hline & 10.1 & 2.34 \\
\hline & 20.1 & 2.54 \\
\hline & 30.1 & 2.66 \\
\hline & 40.1 & 2.64 \\
\hline & 50.1 & 2.64 \\
\hline & 60.1 & 2.78 \\
\hline & 70.1 & 3.02 \\
\hline & 80.1 & 2.94 \\
\hline & 90.1 & 3.00 \\
\hline \multirow[t]{10}{*}{ QQZ500/QQZ353 } & 1.1 & 2.78 \\
\hline & 10.1 & 2.82 \\
\hline & 20.1 & 2.94 \\
\hline & 30.1 & 2.98 \\
\hline & 40.1 & 3.64 \\
\hline & 50.1 & 3.74 \\
\hline & 60.1 & 3.80 \\
\hline & 70.1 & 3.96 \\
\hline & 80.1 & 4.06 \\
\hline & 90.1 & 4.16 \\
\hline \multirow[t]{9}{*}{ QQM764 / QQM772 } & 1.1 & 2.72 \\
\hline & 10.1 & 2.82 \\
\hline & 20.1 & 2.82 \\
\hline & 30.1 & 3.00 \\
\hline & 40.1 & 3.04 \\
\hline & 50.1 & 3.20 \\
\hline & 60.1 & 3.20 \\
\hline & 70.1 & 3.28 \\
\hline & 80.1 & 3.30 \\
\hline
\end{tabular}




\begin{tabular}{|c|c|c|}
\hline $\begin{array}{l}\text { Front Flipper Tag } \\
\text { Numbers }\end{array}$ & $\begin{array}{c}\text { Rate } \\
\text { (clicks/sec) }\end{array}$ & $\begin{array}{c}\text { Latency } \\
\text { (ms) }\end{array}$ \\
\hline & 90.1 & 3.32 \\
\hline \multirow[t]{10}{*}{ QQZ4 $25 / Q Q Z 424$} & 1.1 & 3.26 \\
\hline & 10.1 & 3.70 \\
\hline & 20.1 & 3.86 \\
\hline & 30.1 & 3.92 \\
\hline & 40.1 & 3.96 \\
\hline & 50.1 & 4.28 \\
\hline & 60.1 & 4.18 \\
\hline & 70.1 & 4.32 \\
\hline & 80.1 & 4.40 \\
\hline & 90.1 & 4.08 \\
\hline \multirow[t]{10}{*}{ SSB827/SSB818 } & 1.1 & 3.98 \\
\hline & 10.1 & 4.44 \\
\hline & 20.1 & 4.48 \\
\hline & 30.1 & 4.32 \\
\hline & 40.1 & 3.92 \\
\hline & 50.1 & 4.06 \\
\hline & 60.1 & 4.16 \\
\hline & 70.1 & 4.46 \\
\hline & 80.1 & 5.12 \\
\hline & 90.1 & 5.36 \\
\hline
\end{tabular}


Table 5. $\mathrm{R}^{2}$ and $\mathrm{p}$-values for the regression analysis, performed on 19 loggerhead sea turtles, to determined if a dependency existed between interpeak latencies and stimulus rate. All p-values were significant at $\propto=0.05$.

\begin{tabular}{||l|l|l||}
\hline $\begin{array}{l}\text { Front Flipper Tag } \\
\text { Numbers }\end{array}$ & $\mathrm{R}^{2}$ & P-value \\
\hline QQM792/QQM775 & .966 & $<.0001$ \\
\hline QQM791/QQM794 & .727 & .0017 \\
\hline QQM797/QQM798 & .967 & $<.0001$ \\
\hline QQM605/QQM606 & .938 & $<.0001$ \\
\hline QQM800/QQM785 & .972 & $<.0001$ \\
\hline QQZ417/QQZ401 & .883 & $<.0001$ \\
\hline QQZ409/QQZ408 & .891 & $<.0001$ \\
\hline QQZ426/QQZ427 & .872 & $<.0001$ \\
\hline QQZ407/QQZ406 & .853 & .0001 \\
\hline QQZ429/QQZ430 & .982 & $<.0001$ \\
\hline QQZ441/QQC530 & .909 & $<.0001$ \\
\hline$Q Q Z 437 / Q Q Z 438$ & .916 & $<.0001$ \\
\hline QQZ442/QQZ443 & .849 & .0002 \\
\hline QQZ482/QQZ483 & .840 & .0002 \\
\hline QQZ500/QQZ353 & .932 & $<.0001$ \\
\hline QQZ486/QQZ487 & .920 & .0001 \\
\hline QQM764/QQM772 & .947 & .0001 \\
\hline QQZ425/QQZ424 & .708 & .003 \\
\hline SSB827/SSB818 & .419 & \\
\hline
\end{tabular}


Table 6. Measurements of click intensity and white noise intensity levels for the last point at which the loggerhead sea turtle could distinguish the click.

\begin{tabular}{|c|c|c|c|}
\hline $\begin{array}{l}\text { Front Flipper } \\
\text { Tag Numbers }\end{array}$ & $\begin{array}{l}\text { Click } \\
\text { Intensity } \\
\text { (dB re: } 1 \\
\text { gravity } \\
\text { unit) }\end{array}$ & $\begin{array}{l}\text { White Noise } \\
\text { Intensity } \\
\text { (dB re: 1 } \\
\text { gravity } \\
\text { unit) }\end{array}$ & $\begin{array}{l}\text { Signal-to- } \\
\text { Noise Ratio } \\
\text { (dB re: } 1 \\
\text { gravity } \\
\text { unit) }\end{array}$ \\
\hline QQM605/QQM606 & 2.5 & 6 & -3.5 \\
\hline QQM797/QQM798 & 2.5 & 6 & -3.5 \\
\hline QQM792 / QQM775 & 2.5 & 6 & -3.5 \\
\hline QQM791/QQM794 & -2.5 & 6 & $-8 \cdot 5$ \\
\hline QQZ4 $17 / \mathrm{QQZ} 401$ & -2.5 & 6 & $-8 \cdot 5$ \\
\hline QQZ4 09/QQZ408 & 2.5 & 6 & $-3 \cdot 5$ \\
\hline QQZ426/QQZ427 & 7.5 & 11 & $-3 \cdot 5$ \\
\hline QQZ4 $29 / \mathrm{QQZ} 430$ & 7.5 & 16 & $-8 \cdot 5$ \\
\hline QQZ4 42 /QQZ4 43 & 7.5 & 16 & -8.5 \\
\hline QQZ451/QQZ452 & 7.5 & 11 & $-3 \cdot 5$ \\
\hline QQZ4 $82 / Q Q Z 483$ & 2.5 & 6 & -3.5 \\
\hline $\mathrm{QQZ486/QQZ487}$ & 2.5 & 6 & -3.5 \\
\hline QQZ362 /QQZ363 & 2.5 & 6 & $-3 \cdot 5$ \\
\hline QQZ4 $25 / Q Q Z 424$ & 2.5 & 6 & -3.5 \\
\hline SSB805/SSB806 & -2.5 & 6 & $-8 \cdot 5$ \\
\hline & & $\begin{array}{l}\text { Mean } \pm \\
\text { Standard } \\
\text { deviation }\end{array}$ & $-5.2 \pm 2.4$ \\
\hline
\end{tabular}




\section{DISCUSSION}

\section{Threshold}

The recording of the auditory evoked potentials for tones became very difficult due to the inability of attaining discernable and repeatable responses and only data from six turtles could be recorded. However, the click, a composite of all of the individual tones tested, produced consistently clear responses. This lack of agreement among the tone and click data is thought to be a result of the nature of the stimuli as well as the recording techniques used to attain responses. The responses recorded in this project are reflections of the synchronous discharge of neural fibers found at the base of the hair cells. Hair cells are the sensory receptor cells responsible for converting the motion of the basilar membrane into an electric signal which is then received by the auditory nerve (Yost \& Nielsen, 1977). Each hair cell contains a filter and thus the cell is tuned selectively to a narrow band of frequencies (Crawford \& Fettiplace, 1980; Fettiplace \& Crawford, 1980). A transient stimulus, such as the broadband click, initially stimulates the basal end of the 
cochlea, the site of synchronous activity of neural fibers. The low frequency tone burst, however, appears to stimulate the apical end of the cochlea and thus elicits an asynchronous response of the neurons. If this is the case, and the techniques for auditory evoked potentials record the synchrony of the neural discharge, then the efficiency of the click over the tone burst is apparent.

Another possible problem in recording tone burst data could be related to the volume of the neural response. This problem becomes evident when examining the placement of the electrodes. The loggerhead skull is composed of many layers of thick bone. By stimulating a small portion of the hair cell population with the tone bursts (only those hair cells tuned to the central frequency of the tone), it is possible that the resulting electrical signals were not strong enough in all cases to travel through the bone to the electrodes. Yet by stimulating a larger set of hair cells with the broadband click (a composite of five frequencies), I was able to collect a clear peak $V$ that was trackable in nearly every turtle tested. Due to the loggerheads protected status, however, I was unable to place the electrodes anywhere but unintrusively on top of the skull.

The frequency range of response found in this project can be compared to a study by Ridgeway et al. (1969) in which he examined the threshold levels of the green sea turtle. Ridgeway tested tones on the green sea turtle from 30 to $700 \mathrm{~Hz}$ and found the maximum sensitivity to fall 
between the 300-500 $\mathrm{Hz}$ frequency range. I found similar results with the tone burst data. Using a variety of stimuli, the maximum sensitivity fell between $250-1000 \mathrm{~Hz}$. The computer was unable to test below $250 \mathrm{~Hz}$ so I am unable to speculate on the low end of the loggerhead's sensitivity. However, I was able to test up to $8 \mathrm{kHz}$ and found that over $1000 \mathrm{~Hz}$ the sensitivity fell off drastically.

Comparing the sound pressure data from the green sea turtle (Ridgeway et al., 1969) to loggerhead sea turtles, a larger discrepancy is found. Ridgeway (1969), using tones, found the sound pressure in dynes $/ \mathrm{cm}^{2}$ to range from -5 to $-35 \mathrm{~dB}$ for the 100-700 $\mathrm{Hz}$ range. I could only record the sound pressure level successfully for the click, a stimuli which encompassed approximately the same frequency range, and found the mean threshold to be $8.5 \mathrm{~dB}$ re: 1 dyne $/ \mathrm{cm}^{2}$. This dissimilarity of results can possibly be explained by a difference in recording techniques. Ridgeway collected cochlear potentials with electrodes surgically inserted into the paralymphic spaces. This technique would allow for greater detection by the electrodes. This disparity of results could also be explained by a dissimilarity between species. However, I do not believe that recordings using sound pressure levels in air as a reference are appropriate when collecting data from sea turtles. I ran this calibration in the laboratory so that my results could be compared to the limited published research on turtle hearing sensitivity: However, there is convincing research which 
strongly suggests that sea turtle auditory perception is through bone rather than air conduction. The tympanum appears to be a poor aerial receptor, and displacement of the columella was not significantly changed by the removal of the tympanum (Moffat and Capranica, 1978). Furthermore, except for females nesting on the beach and green sea turtles basking in the Pacific, sea turtles spend the majority of their time underwater (Keinath, 1993) and thus it would be unlikely that the sea turtle would have a developed and functional air conduction hearing mechanism. The bones of the shell and skull, much denser than sea water, could serve as a receptor for vibrations in underwater sound fields (Lenhardt et al., 1983). In this scenario the tympanum is displaced outward as a mechanism for the release of the columella rather than inward as an air conductive sound receptor. Consequently, the use of vibratory stimuli, placing a vibrator against the turtle skull and relaying stimuli through the bone, is a more appropriate technique and likely to result in a more accurate measure of the sensitivity of the sea turtle hearing mechanism. Ideally, recording of auditory evoked potentials in an underwater environment large enough to eliminate the harmonics due to reflection of sound would result in thresholds more representative of the turtle's true hearing ability.

Loggerhead's ability to detect low frequency sounds has been theorized to be involved in natal beach homing behavior 
(Dodd, 1988). Tagging data reveals that adult females repeatedly return to the same nesting beach, and possibly the same beach from which they hatched. Furthermore, it has been recorded that surf waves have a signature sound distinct to each beach (Bowen et al., 1993). The sounds of the beach may be distinct enough to serve as a cue for loggerheads when nesting. However, this theory implies that the turtle is able to discriminate between frequencies, a feature of sea turtle hearing that has not yet been investigated.

\section{Repetition Rate}

Auditory evoked potentials reflect synchronous electrical activity and thus, as found in the threshold section of this study, clicks represent the best stimulus for evoking the synchronized response. of all of the peaks (Jewett bumps) found in these recordings, I was most interested in peak I and peak $V$. Latencies of these peaks are a convenient and useful measurement for evaluating auditory evoked potentials. Absolute latencies are variable depending on a number of factors, including temperature and stimulus intensity. However the interpeak latencies, the time between the firing of two peaks, is a consistent and reliable response among individuals.

The direct dependency of latency on rate reflects the reduction in efficacy of the stimulus with an increase in click rate to activate a synchronous progression of the 
signal down the auditory pathway. After the neuron discharges, it remains in a refractory period, a period of no activity. This refractory period limits the number of times the neuron can discharge in a second. With an increasingly high rate of the stimulus, the neurons were unable to respond in a synchronized fashion and thus the signal required a longer period of time to activate the path.

An application for the interpeak latencies could be the identification of brain lesions. In the medical field, auditory evoked potentials have been used extensively in human diagnostic techniques to identify brainstem disorders and lesions (Markand, 1994). In patients who show no clinical symptoms, auditory evoked potentials have been capable of detecting lesions of the brainstem in one third of the cases. A common abnormality observed is the prolongation of the interpeak latency of peaks $I$ and $V$.

This same diagnostic technique may be applicable to sea turtles. Recently, a new disease of the brain of loggerheads has been identified as Giant cell Meningoencephalitis (GME) (George et al., in press). GME has been identified by necropsies performed on loggerheads who exhibited signs of central nervous system disorders: lethargy, inactivity, and uncoordinated movement. The lesions were found in the regions of the medulla, optic lobe, and cerebellum. This disease goes undetected until symptoms are severe (George et al., in press). However, it 
may be possible to test clinically for this brain lesion in loggerheads before the lesion becomes symptomatic. From the rate experiment we know that the interpeak latencies are convenient to measure and consistently increase with the rate of the stimulus. By developing a baseline for conduction time for peaks $I$ and $V$ in normal turtles, abnormalities in the interpeak latencies may allow researchers to examine the occurrence and possible treatments for GME brain disease.

\section{Masking Experiment}

Signal detection for marine species can be masked by the often high level of background noise found in the oceans. Ambient noise in the oceans can arise from a number of sources, including: surface waves, seismic activity shipping, and biological activity. The frequency range of ambient noise is often localized in the low frequency end of the spectrum (Hawkins and Myrberg, 1983), the range at which loggerheads hear. Thus it is possible that ambient noise actually designates the limit at which loggerheads can detect an acoustic signal.

This masking experiment investigated the limits at which the loggerhead can distinguish a signal through ambient noise by examining the point at which the noise disrupts the synchrony of the neural response. The white noise used in the study was composed of a similar spectrum as that found in the click. Masking is most effective in 
concealing a signal which contains the same frequencies and thus this scenario was constructed to produce the highest level of masking.

These results, a signal to noise ratio of $-5.2 \mathrm{~dB}$ re: 1 gravity unit, may prove to be misleading. The click stimulus is a broadband spectrum of energy as is the white noise. The difference between the two, however, is that white noise is steady with all possible frequencies represented equally (Gelfand, 1990) while the click, when activated by the bone vibrator, has a transient character. This transience, an abrupt on and off sound, can cause the vibrator to resonate around a single frequency (Green, 1976). Consequently, the overall click decibel levels, as calculated by the accelerometer, may be an underestimate of the actual amount of intensity at a particular frequency, the resonant frequency.

Even with this apparent exaggeration of the signal to noise ratio, these results do confirm that the loggerhead has the ability to distinguish a signal through ambient noise, possibly at a relatively high level of noise. An adaptation of the hearing mechanism to reduce interference from noise would certainly be advantageous for the sea turtle. Due to the high and variable level of ambient noise centered around the low frequency range in the oceans, signal detection would only be possible if the sea turtle were able to discriminate sound through an elevated level of noise. 


\section{Conclusions}

This study represents one of the first steps in understanding the loggerhead's hearing mechanism. The methodology for collecting auditory evoked potentials from loggerhead sea turtles was developed and threshold levels were measured. Auditory responses for loggerheads were most sensitive from at least 250 to $1000 \mathrm{~Hz}$. Secondly, the latencies of peak I and peak $V$ were dependent on the rate and thus the interpeak latency increased with the increase in stimulus rate. Finally, loggerhead sea turtles appear to be able to distinguish signals through a relatively high level of ambient noise.

At present, evoked potential methods may be utilized in two fields of applied research: in the development of repelling devices and the identification of diseases. To return to the initial catalyst of this study, repelling devices are being developed to repel turtles away from areas where human activities place them in danger. The conclusions of this research can certainly define the frequencies and intensity for a possible repelling device. Moreover, the methods of evoked potentials laid out by this project can be used as a tool to protect the sea turtle during the development of repelling devices. Researchers have an obligation to conduct their studies unintrusively and to insure that damage is not being caused to the species they are trying to protect. By examining the threshold levels of an individual before and after testing a potential 
repelling device, the researcher can take precautions to avoid damage to the turtle's hearing mechanism. These methods may also prove beneficial to the further identification of brain diseases, such as Giant cell Meningoencephalitis. If able to detect GME before the onset of symptoms, it might be possible to record the progression of the disease as well as test possible drugs as curative agents.

There are, however, many questions about sea turtle hearing yet to answer. Does the threshold to vibratory stimulus change when the turtle is submerged? The first step is to perform electrophysiological trials in a tank, one which is large enough to prevent the reflection of low frequencies. The second question which arises from this research is whether the loggerhead uses hearing in nature and why. Is the loggerhead ear a useless vestige or does hearing play a role in the turtle's life history? The use of hearing by sea turtles can be investigated by performing underwater localization experiments to examine whether sea turtles can be conditioned to sound stimuli. Finally, do all sea turtles hear by similar methods, specifically bone conduction? How does the leatherback, a species which has exchanged its hard shell for a leathery one, hear? All of these questions may be answerable in the very near future. 
Appendix. Calibration graphs for tones and click stimuli. 
A-1. Frequency output of the bone vibrator, as measured by a real time spectral analyzer, for $250 \mathrm{~Hz}$.

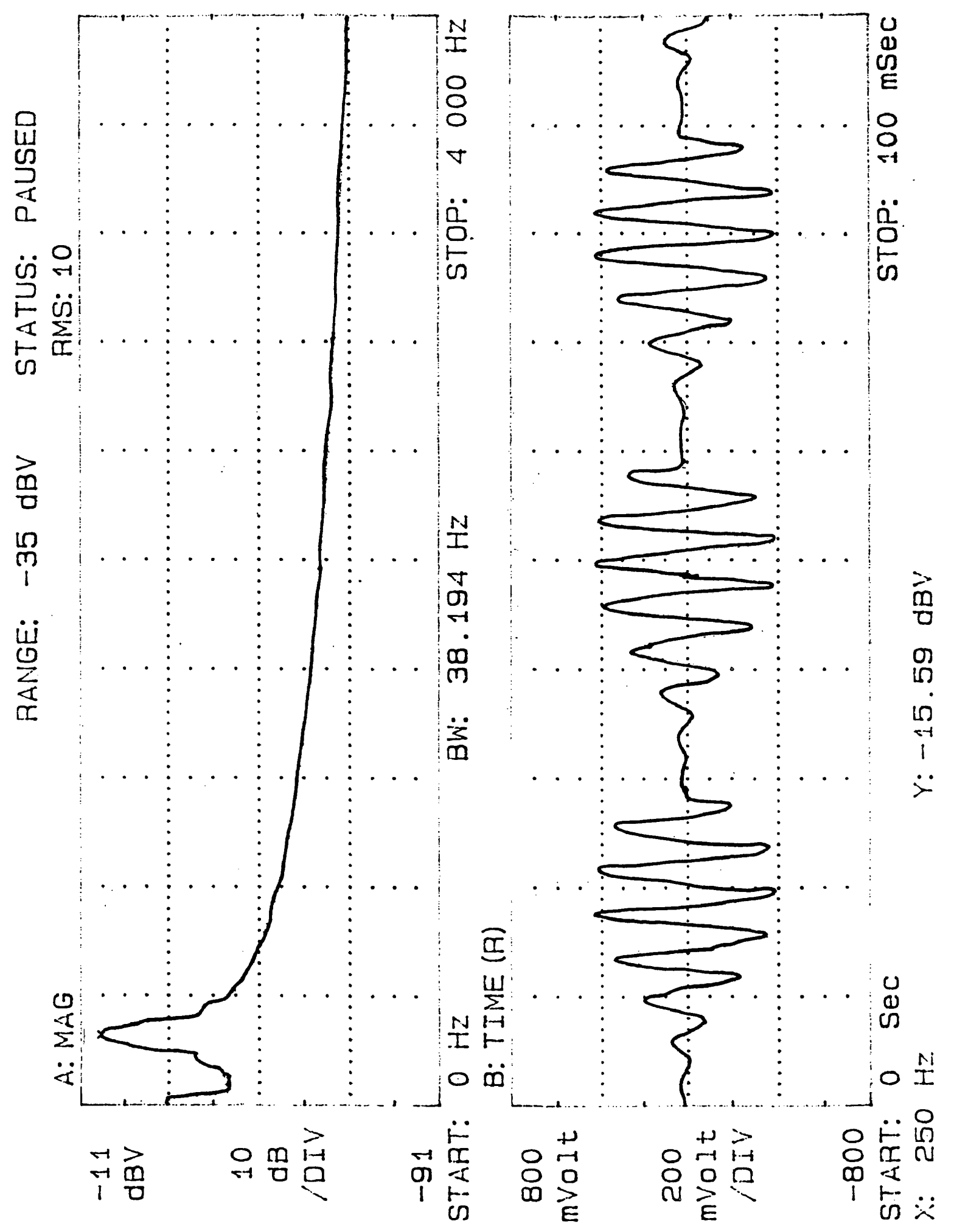


A-2. Frequency output of the bone vibrator, as measured by a real time spectral analyzer, for $500 \mathrm{~Hz}$.

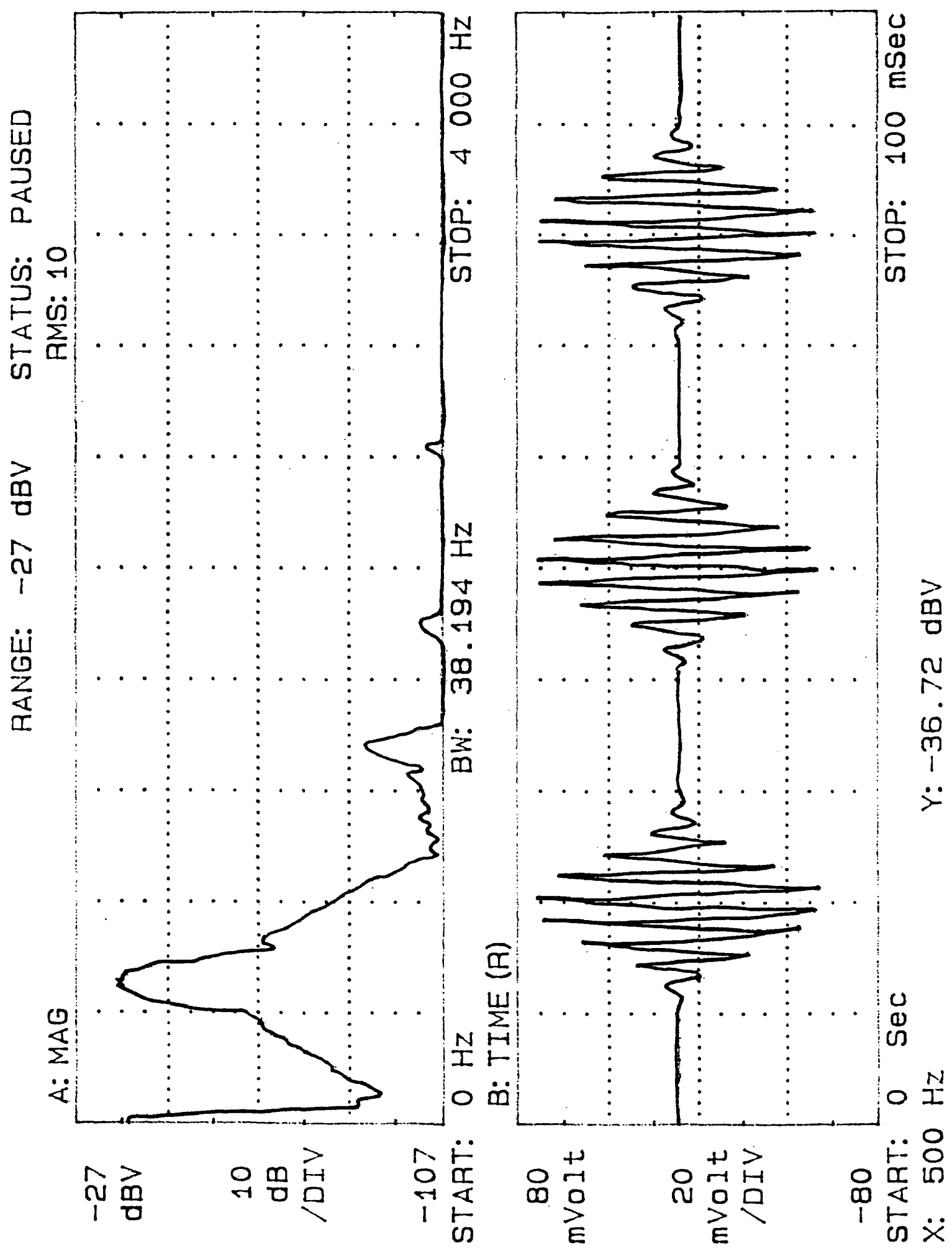


A-3. Frequency output of the bone vibrator, as measured by a real time spectral analyzer, for $750 \mathrm{~Hz}$.

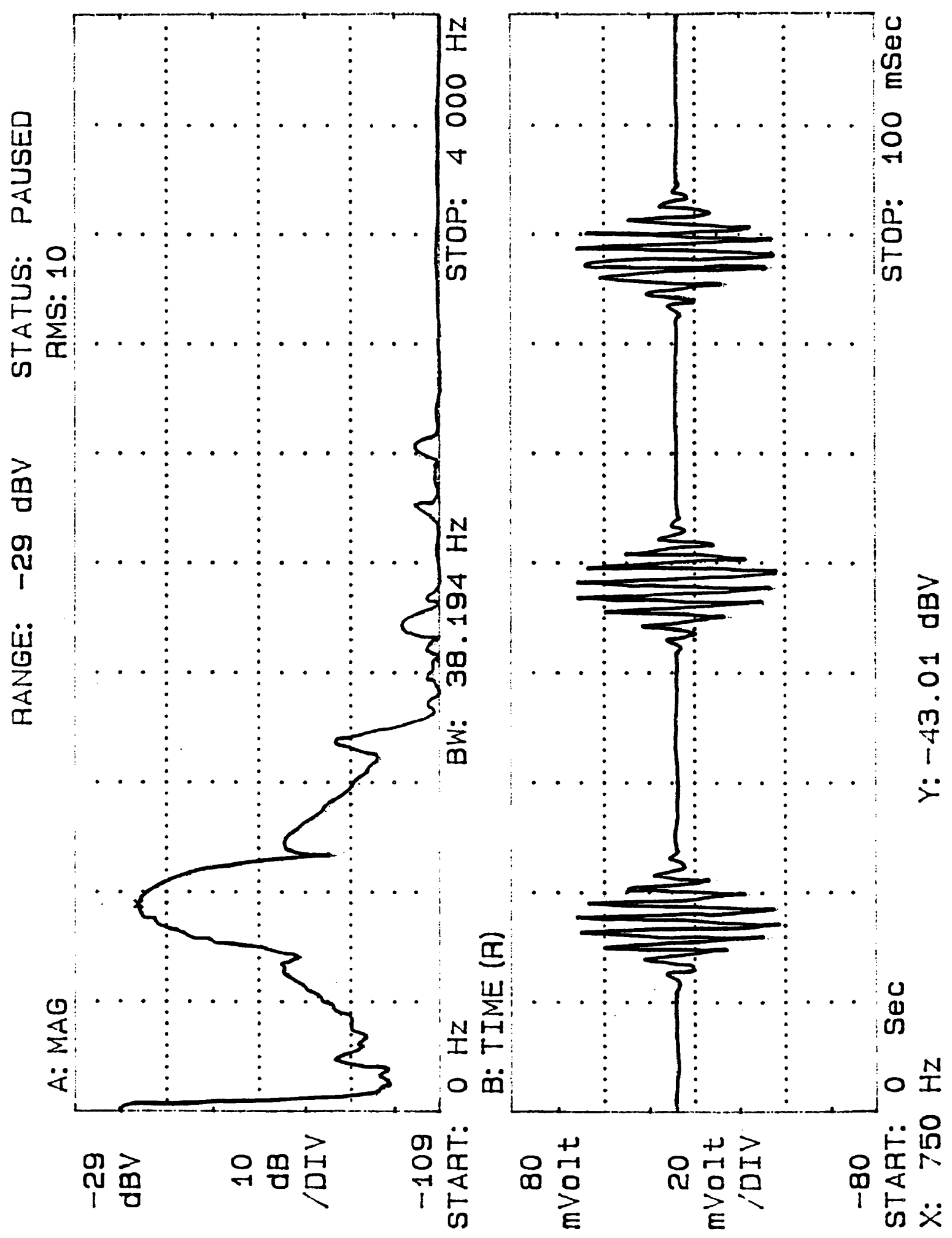


A-4. Frequency output of the bone vibrator, as measured by a real time spectral analyzer, for $1000 \mathrm{~Hz}$.

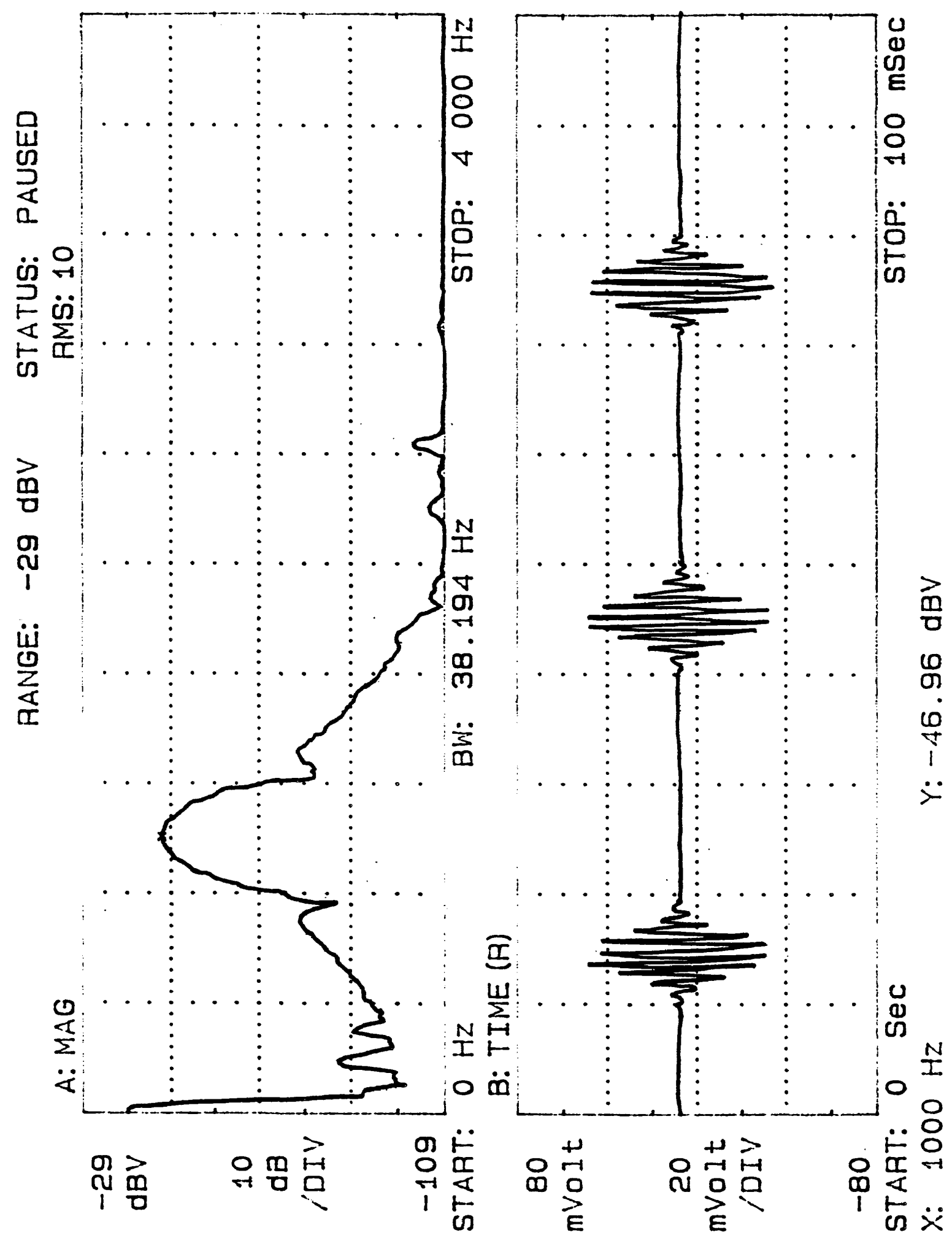


A-5. Frequency output of the bone vibrator, as measured by a real time spectral analyzer, for the click.

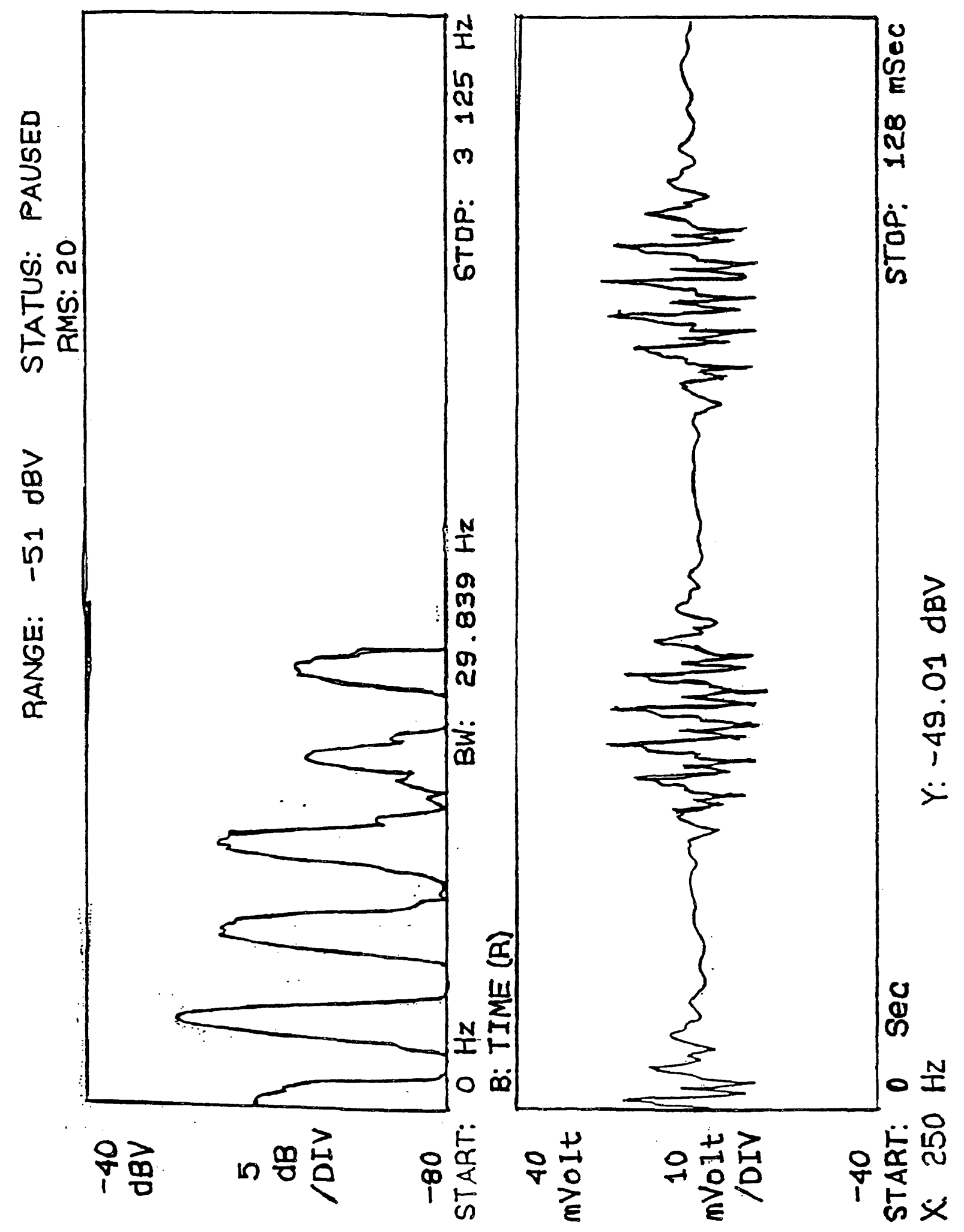




\section{LITERATURE CITED}

Adrian, E.D., K.J.W. Craik, and R.S. Sturdy. 1938. The electrical response of the auditory mechanism in coldblooded vertebrates. Proc. Royal Soc. London. 125: 435-455.

Andrews, 0 . 1915. The ability of turtles to discriminate between sounds. Bull. Wisconsin Nat. His. Soc. 13: 189-195.

Art, J.J., A.C. Crawford, R. Fettiplace, and P.A. Fuchs. 1985. Efferent modulation of hair cell tuning in the cochlear of the turtle. J. Physiol. 360:397-421.

Bekesy, G. 1948. Vibration of the head in a sound field, and its role in hearing by bone conduction. J. Acoust. Soc. Am. 20: 749-760.

Bowen, B, J.C. Avise, J.I. Richardson, A:B. Meylan, D. Margaritoulis, S.R. Hopkins-Murphy. 1993. Population structure of loggerhead turtles (Caretta caretta) in the northwestern Atlantic ocean and Mediterranean sea. Conv. Biol. 7:834-844.

Buckwald, J.S. and C.M. Huang. 1975. Far-field acoustic response: origins in the cat. Science. 189: 382-384.

Carr, A.F., Jr., L. Ogren, and C. Mcvea. 1981. Apparent hibernation by the Atlantic loggerhead turtle, Caretta caretta off Cape Canaveral, Florida. Biol. Conserv. 19: 7-14.

Chernomordikov, V.V. 1958. On the physiology of the auditory analyzer in turtles. Zhurnal Vysshei Nervnoi Deyatel I.P. Pavlova. 8: 102-108.

Chiappa, K.H., K.J. Gladstone, and R.R. Young. 1979. Brain stem auditory evoked responses: studies of the waveform variations in 50 normal human subjects. Arch. Neurol. 36: 81-87.

Crawford, A.C. and R. Fettiplace. 1980. The frequency selectivity of auditory nerve fibres and hair cells in the cochlear of the turtle. J. Physiol. 306: 79-125. 
Dickerson, D.D. 1991. Entrainment of sea turtles by hopper dredges in Cape Canaveral and King's Bay ship channels. US Army Corps of Engineers Information Exchange Bulletin, Vol.D-91-3.

Dodd, C.K., Jr. 1988. Synopsis of the biological data on the loggerhead sea turtle (Caretta caretta) (Linnaeus 1758). U.S. Fish Wildl. Serv. Biol. Rep. 14: 39-71.

Don, M. and J.J. Eggermont. 1978. Analysis of the clickevoked brainstem potentials in man using a high-pass noise masking. J. Acoust. Soc. Am. 63: 1084-1092.

Fabiani, M., H. Sohmer, C. Tait, M. Gafni, and R. Kinarti. 1979. A functional measure of brain activity: brainstem transmission time. Electroenceph. Clin. Neurophysiol. 47: 483-491.

Fettiplace, R. and A.C. Crawford. 1980. The origin of tuning in turtles cochlear hair cells. Hearing Research. 2: 447-454.

Foa, C. and A. Peroni. 1930. Primi tentativi di registrazione delle correnti d'azione del nervo acustico. Archivi di Fisiol. 28: 237-241.

Gelfand, S.A. 1990. Hearing: An Introduction to Physchological and Physiological Acoustics. Marcel Dekker, Inc.: New York.

George, R., R. Wolke, and J. Keinath. In press. Encephalitis: a new reason why apparently healthy sea turtles strand in warm weather. In: Proceeding of the 12th annual workshop on sea turtle conservation biology.

Gibson, W.P.R. 1982. The use of auditory evoked potentials for the estimation of hearing. In: A.M. Halliday (ed.) Evoked Potentials in Clinical Testing. Churchhill Livingstone: Ediburgh.

Green, D.M. 1976. An Introduction to Hearing. Lawrence Erlbaum Assoc.: Hillsdale.

Grossblatt, N., ed. 1990. Decline of the sea Turtles: Causes and Prevention. National Academy Press: Washington D.C.

Hawkins, A.D. and A.A. Myrberg, Jr. 1983. Hearing and sound communication under water. In: B. Lewis (ed.) Bioacoustics: A Comparative Approach. Academic Press: London, p347-405. 
Hopkins, S. and J. Richardson. 1984. A recovery plan for marine turtles. Washington, D.C.: U.S. Government Printing office.

Jewett, D.L. 1970. Volume conducted potentials in response to auditory stimuli as detected by averaging in the cat. Electroencephalogr. Clin. Neurophysiol. 28: 609-618.

Jewett, D.L., M.N. Romano, and J.S. Williston. 1970 . Human auditory evoked potentials: possible brainstem components detected on the scalp. Science. 167: 15171518 .

Joyce, J.C. 1982. Protecting sea turtles. The Military Engineer, No. 481, July-August, p. 282-285.

Karimova, M.M. 1958. The conditioned reflex character of the auditory analyzer in turtles. Zhurnal Vysshei Nervnoi Deyatel I.P. Pavlova. 8: 102-108.

Keinath, J.A. and J.A. Musick. 1993. Movements and diving behavior of a leatherback turtle, (Dermochelys coriacea). Copeia. 4: 1010-1017.

Kuroda, R. 1923. Studies on audition in reptiles. $J$. Comp. Psychol. 3: 27-36.

Kuroda, R. 1925. A contribution to the subject of hearing in tortoises. J. Comp. Psychol. 5: 285-291.

Lenhardt, M.L. 1982. Bone conduction hearing in turtles. $J$. Aud. Res.. 22: 153-160.

Lenhardt, M.L., S. Bellmund, R. Byles, and J. Musick. 1983. Marine turtle reception of bone conducted sound. $J$. Aud. Res. 23: 119-125.

Lenhardt, M.L. and S. W. Harkins. 1983. Turtle shell as an auditory receptor. J. Aud. Res. 23: 251-260.

Lenhardt, M.L., R. C.Klinger, and J. A. Musick. 1985. Marine turtle middle-ear anatomy. J. Aud. Res. 25:6672 .

Manley, G. 1970. Comparative studies of auditory physiology in reptiles. Z. Vergl. Physiol. 67: 363381 .

Manley, G. 1974. Activity patterns on neurons in the peripheral auditory system of some reptiles. Brain Behav. Evol. 10: 244-256.

Markand, O.N. 1994. Brainstem auditory evoked potentials. 
J. Clin. Neurophysiol. 11: 319-342 .

MCGill, T.E. 1960. A review of hearing in amphibians and reptiles. Psychol. Bull. 57: 165-168.

Moffat, A.J.M. and Capranica, R.R. 1978. Middle ear sensitivity in anurans and reptiles measured by light scattering spectroscopy. J. Com. Physiol. 127: 97107.

Patterson, W.C. 1966. Hearing in the turtle. J. Aud. Res. $6: 453-464$.

Paton, J.A., A.J. Moffat, and R.R. Capranica. 1976. Electrophysical correlates of basilar membrane motion in the turtle. J. Acoust. Soc. Am. 59: 546.

Poliakov, K. 1930. Zur Physiologie des Riech-und Horanalysators bei der Schildkrote Emys orbicularis. Russkii fiziol. Zhurnal. 13: 161-177.

Pratt, H. and H. Sohmer. 1976. Intensity and rate functions of cochlear and brainstem evoked responses to click stimuli in man. Arch. Oto-Rhino-Laryng. 212: 85-92.

Ridgeway, S.H., E.G. Wever, J.G. McCormick, J. Palin, and J.H. Anderson. 1969. Hearing in the giant sea turtle, Chelonia mydas. Proc. Nat. Acad. Sci. 64: 884-890.

Rowe, M.J., III. 1978. Normal variability of the brainstem auditory evoked response in young and old adult subjects. Electroenceph. Clin. Neurophysiol. 44: 459470 .

Spehlmann, R. 1985. Evoked Potential Primer: Visual, Auditory, Somatosensory Evoked Potentials in Clinical Diagnosis. Butterworth-Heinemann: Boston.

studt, J. F. 1985. Amelioration of maintenance dredging impacts on sea turtles, Canaveral harbor, Florida, p5558. In: W. N. Witzell (ed.), Ecology of East Florida Sea Turtles. NOAA Tech. Rept. NMFS 53.

Tavolga, W.N. and J. Wodinsky. 1963. Auditory capacities in fishes. Bull. Amer. Mus. Nat. Hist. 126: 179-239.

Tonndorf, J. 1972. Bone conduction. In: Tobias, J.V.(ed.) Foundations of Modern Auditory Theory. Vol II. New York: Academic Press, pp 197-237.

Wever, E.G. 1931. Auditory nerve experiments in animals and their relation to hearing. Laryngoscope. 41: 387- 
391 .

Wever, E.G. 1978. The Reptile Ear: Its Structure and Function. Princeton University Press: Princeton, pp 832-922.

Wever, E.G. 1949. Theory of Hearing. John Wiley and Sons, Inc.: N.Y, pp 399-423.

Wever, E.G. and J. A. Vernon. 1956. Sound transmission in the turtle's ear. Proc. Natl. Acad. Sci. 42: 229- 299.

Yost, W.A. and D.W. Nielsen. 1977. Fundamentals of Hearing. Holt, Reinhart and Winston: New York.

Zar, J. 1984. Biostatistical Analysis. Prentice Hall: Englewood Cliffs, PP 261-290. 


\section{VITA}

Soraya E. Moein

Born January 29, 1970, in Fairfax, Virginia. Graduated from Marist High School in 1988. Earned B.A. in Biology from the Univerisity of Virginia in 1992. Entered the masters program at the College of William and Mary, school of Marine Science in 1992 